\title{
Carbon isotope stratigraphy and ammonite biochronostratigraphy across the Sinemurian-Pliensbachian boundary in the western Iberian margin
}

\author{
LuÍS V. DUARTE, MARIA JOSÉ COMAS-RENGIFO, RICARDO LOURO SILVA, RICARDO PAREDES \\ \& ANTONIO GOY
}

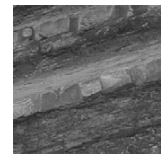

\begin{abstract}
Here, we present an integrated stratigraphical study across the Sinemurian-Pliensbachian interval cropping out into the Portuguese reference section of S. Pedro de Moel (Lusitanian Basin). Characterized by marl-limestone alternations of the Água de Madeiros Formation (subdivided into Polvoeira and Praia da Pedra Lisa members), this succession is particularly dominated by organic-rich facies (black shales) and contains a diverse fauna of benthic and nektonic macrofossils. This stratigraphic and sedimentary setting is the basis for a high-resolution carbon isotope study, constrained by new ammonite biochronostratigraphic determinations and other palaeontological data. The new ammonite collections characterize the Oxynotum and Raricostatum chronozones and the Raricostatum, Macdonnelli and Aplanatum subchronozones, and accurately identify the Sinemurian-Pliensbachian boundary in this western Iberian margin setting. Carbon isotope measurements were made from bulk carbonate $\left(\delta^{13} \mathrm{C}_{\text {carb }}\right)$ from 351 samples, representing the Oxynotum to earliest Jamesoni (early Taylori) Chronozone intervals. The carbon isotope values exhibited a large range, varying between $+2.85 \%$ in the Oxynotum Subchronozone to very negative values observed in some limestone beds from the Raricostatum Subchronozone (lowest reaching -6.7\%o), a variation clearly controlled by lithological and facies changes. Despite these strong anomalous isotopically light values (below $-2 \%$ ), which are clearly associated with organic matter degradation and early diagenesis, the $\delta^{13} \mathrm{C}_{\text {carb }}$ curve shows a long-term negative trend across the Oxynotum to the early Taylori Subchronozone interval. This tendency is reversed around $5 \mathrm{~m}$ above the Sinemurian-Pliensbachian boundary, and the $\delta^{13} \mathrm{C}_{\text {carb }}$ values become positive correlative with an absence of organic matter and argillaceous sediments in the limestone beds of Praia da Pedra Lisa Member. Although the $\delta^{13} \mathrm{C}$ data recorded across the Sinemurian-Pliensbachian of the Lusitanian Basin had been controlled by internal depositional conditions, the general evolution of carbon isotopes agrees with the trend recognized in other basins. - Key words: carbon isotopes, ammonite biochronostratigraphy, organic-rich marly limestone, Sinemurian-Pliensbachian boundary, Portugal.
\end{abstract}

Duarte, L.V., Comas-Rengifo, M.J., Silva, R.L., PARedes, R. \& GoY, A. 2014. Carbon isotope stratigraphy and ammonite biochronostratigraphy across the Sinemurian-Pliensbachian boundary in the western Iberian margin. Bulletin of Geosciences 89(4), 719-736 (7 figures, appendix). Czech Geological Survey, Prague. ISSN 1214-1119. Manuscript received August 5, 2013; accepted in revised form March 19, 2014; published online July 8, 2014; issued September 30, 2014.

Luís V. Duarte (corresponding author), Departamento de Ciências da Terra, Faculdade de Ciências e Tecnologia, Universidade de Coimbra, 3000-272 Coimbra, Portugal, and IMAR-CMA, Universidade de Coimbra, 3000-272 Coimbra, Portugal; lduarte@dct.uc.pt • María José Comas-Rengifo, Departamento de Paleontología, Facultad de Ciencias Geológicas, Universidad Complutense de Madrid, José Antonio Nováis 2, 28040 Madrid, España • Ricardo Louro Silva, Basin and Reservoir Lab, Department of Earth Sciences, Faculty of Sciences, Dalhousie University, Room 3060, Life Science Center, Halifax, NS B3H 4R2 Canada • Ricardo Paredes, IMAR-CMA, Universidade de Coimbra, 3000-272 Coimbra, Portugal, and Departamento de Paleontología, Facultad de Ciencias Geológicas, Universidad Complutense de Madrid, José Antonio Nováis 2, 28040 Madrid, España • Antonio Goy, Departamento de Paleontología, Facultad de Ciencias Geológicas, Universidad Complutense de Madrid, José Antonio Nováis 2, 28040 Madrid, España

The Lusitanian Basin (LB), located on the western Iberian passive margin of the Atlantic (Fig. 1A), provides an excellent record of the Early Jurassic time interval. Primarily comprising thick marine carbonate deposits, part of this succession, namely the Upper Sinemurian-Pliensbachian interval, is composed of hemipelagic marl-limestone alternations (e.g. Soares et al. 1993; Azerêdo et al. 2003; Duarte et al. 2004b, 2010; Duarte 2007), biostratigraphically 

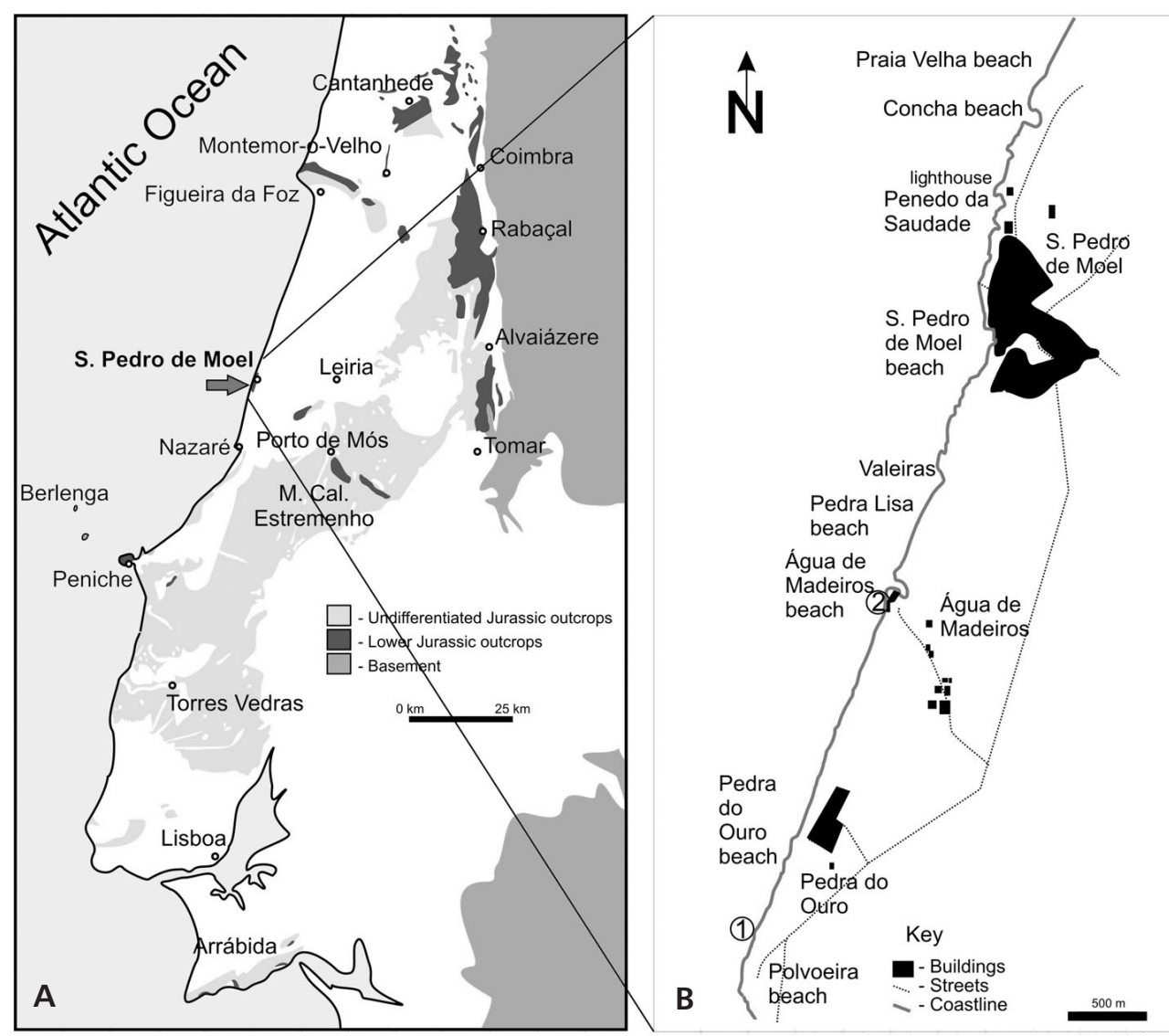

Figure 1. A - simplified geological map of the central-northern part of the Lusitanian Basin (Portugal) with the location of the main Lower Jurassic hemipelagic deposits. - B - sketch map of coastal area of S. Pedro de Moel with the location of the two studied sections: 1 - Polvoeira; 2 - Água de Madeiros. - $\mathrm{C}$ - generic facies and stratigraphic chart for the Hettangian-Lower Pliensbachian interval of the Lusitanian Basin (adapted from Duarte et al. 2010).

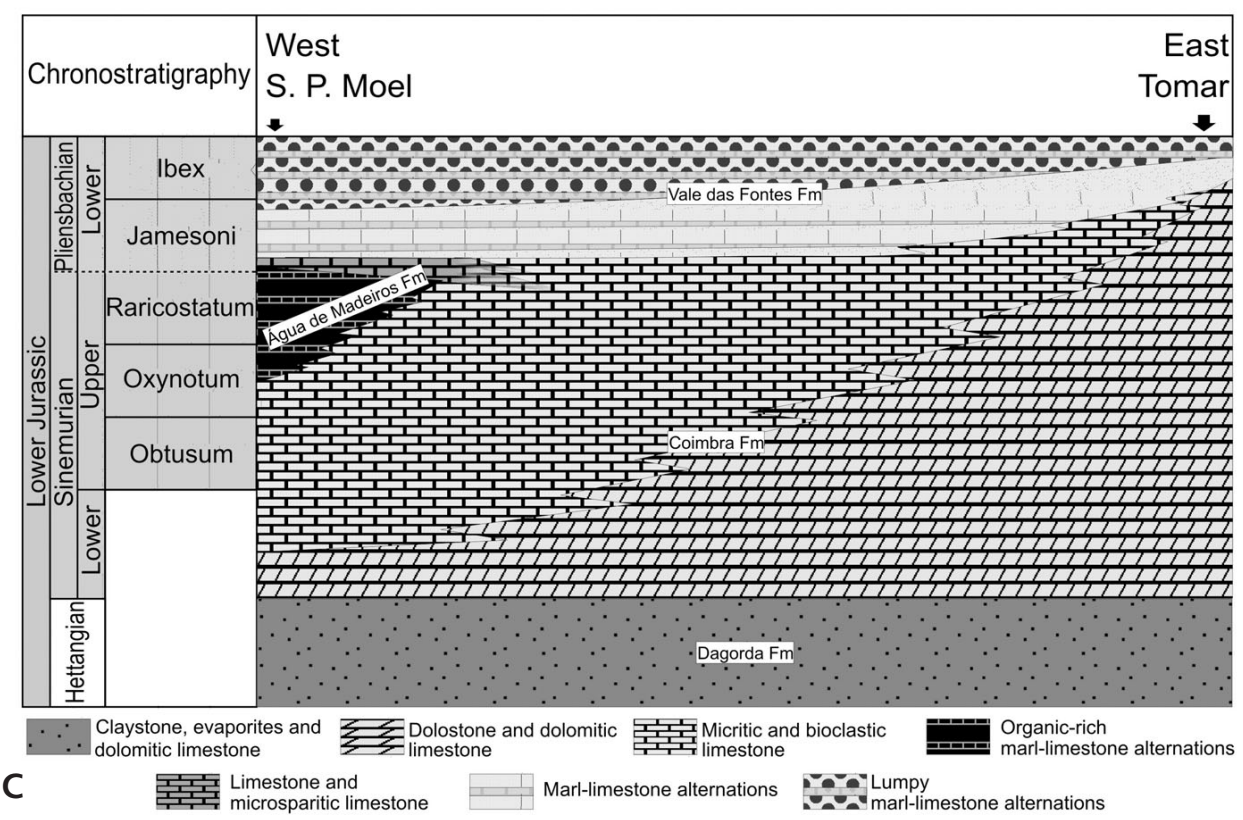

well controlled through accurate ammonite determinations (e.g. Mouterde 1967a, Phelps 1985, Dommergues 1987, Comas-Rengifo et al. 2013, and references therein) and calcareous nannofossils (Oliveira et al. 2007, Regianni et al. 2010, Mattioli et al. 2013). A characteristic feature of the Upper Sinemurian and Pliensbachian sedimentation in the LB is the richness in organic matter, making it one of the most important stratigraphic intervals of hydrocarbon source rocks (e.g. Oliveira et al. 2006; Duarte et al. 2010, 2012; Silva et al. 2011, 2012; Correia et al. 2012; Poças 
Ribeiro et al. 2013; Silva 2013). Here, we present a highresolution integrated stratigraphic study of the Upper Sinemurian-lowermost Pliensbachian carbonate deposits (Água de Madeiros Formation), cropping out into the S. Pedro de Moel area (Fig. 1A, B). This work comprises a carbon isotope analysis of this interval in the westernmost European domain, supported through new biostratigraphic interpretations, considered together with other previously published lithostratigraphic, palaeontological (benthic macrofauna) and geochemical (total organic carbon, TOC) data. The S. Pedro de Moel section presents the most complete record of Sinemurian and Lower Pliensbachian ammonites of the LB (e.g. Pompeckj 1898, 1906; Choffat 1903-1904; Mouterde 1967b; Antunes et al. 1981; Mouterde et al. 1981; Dommergues 1987; Dommergues et al. 2004, 2010; Duarte et al. 2010; Meister et al. 2012; Comas-Rengifo et al. 2013). In this study, we present new precise biostratigraphic determinations, particularly in terms of the definition of some zonal and subzonal boundaries of the Late Sinemurian (Oxynotum and Raricostatum chronozones). This improved biochronostratigraphic zonation will be useful in future stratigraphic correlation and palaeoenvironmental studies involving this interval in the Iberia margin. In addition, our high-resolution carbon isotope data build on and extend the conclusions of the recent chemostratigraphic studies of Korte \& Hesselbo (2011), Riding et al. (2012) and Jenkyns \& Weedon (2013). Developed in different geological contexts of UK Jurassic basins, the cited studies suggest that carbon isotope evolution during the Late Sinemurian (since the Oxynotum Chronozone) to earliest Pliensbachian is marked by global scale geochemical events (see Korte \& Hesselbo 2011, Riding et al. 2012).

\section{Geological setting}

The LB is a narrow and small north-south elongated basin, bordered in the east by the Iberian Massif and to the west by the Variscan (granitic and metamorphic) Berlenga Horst (Fig. 1A). This basin originated during the Triassic, resulting from an extensional phase that preceded the opening of the Central Atlantic Ocean. From the Jurassic to late Cretaceous, the sedimentary infill records a great variety of sediments and facies that reflect palaeoenvironmental changes. In terms of the LB sedimentary evolution, several phases have been identified, each bounded by regional unconformities (e.g. Wilson et al. 1989, Alves et al. 2002, among others). The first cycle, ranging from the Triassic to the Middle Jurassic (Callovian) (Soares et al. 1993, Azerêdo et al. 2003), includes the stratigraphic interval presented and discussed in the present study (Fig. 1C).

In the LB, the Lower Jurassic generally comprises marine carbonate deposits (see Soares et al. 1993, Azerêdo et al. 2003, Duarte et al. 2004b). The base of the Jurassic



Figure 2. Synthetic stratigraphic log of the Sinemurian-Lower Pliensbachian succession in the S. Pedro de Moel area (adapted from Duarte et al. 2008, 2012; Azerêdo et al. 2010). 
succession, probably Hettangian, is marked by a finegrained, primarily siliciclastic sediments with some dolomitic and evaporitic intercalations (Dagorda Fm.). The first predominantly carbonate unit represented at a basinal scale, the Coimbra Fm. (Sinemurian), overlies the Dagorda Fm. (Fig. 1C). The Coimbra Fm. comprises a succession of dolostone and limestone, with the latter lithotype better expressed at the top of the unit and in the most western sectors. This lithotype corresponds to a marginal-marine palaeoenvironmental setting (Azerêdo et al. 2010). During the Late Sinemurian, particularly in the western part of the basin (Peniche, S. Pedro de Moel and Figueira da Foz localities, Fig. 1A), the succession is characterized by marl-limestone alternations with common ammonites and black shale, belonging to the Água de Madeiros Fm. This unit marks the onset of the development of open marine conditions in the basin and is subdivided into the Polvoeira and Praia da Pedra Lisa members (Duarte \& Soares 2002). This fine-grained sedimentation extends throughout the basin in the Lower Pliensbachian-Upper Toarcian interval, corresponding to the Vale das Fontes, Lemede and S. Gião formations (Duarte \& Soares 2002; Duarte et al. 2004b, 2010; Duarte 2007).

\section{The Lower Jurassic at S. Pedro de Moel}

S. Pedro de Moel is a small town located on the coast approximately $110 \mathrm{~km}$ north of Lisbon (Fig. 1A). In this area, the Lower Jurassic carbonate outcrops are restricted to the coastline (Fig. 1B), including the Lower Sinemurian to Middle Toarcian interval, in an intensely folded and faulted succession (see Duarte et al. 2008, 2012). Despite this complex structural setting the Sinemurian record in these exposures is particularly important. In the present study we observed the best and most continuous succession of the Coimbra Fm., the type-section of the Água de Madeiros Fm. and its two members (e.g. Duarte \& Soares 2002; Duarte et al. 2008, 2010, 2012; Azerêdo et al. 2010) (Fig. 2). The occurrence of ammonites from the Obtusum Chronozone of S. Pedro de Moel, the oldest known record in the LB, allowed dating the succession from the middle part of the Coimbra Fm. upwards (Dommergues et al. 2004, 2010).

\section{Material and methods}

Although this study makes use of stratigraphic and sedimentological data from other locations within the LB (Fig. 1A), the study was primarily centered in the S. Pedro de Moel region, where there are two complementary sections of the Upper Sinemurian to Lower Pliensbachian, cropping out at the Polvoeira and Água de Madeiros beaches (Figs 1B and 3). These two localities, considered as type-sections of the Polvoeira and Praia da Pedra Lisa members (Duarte \& Soares 2002), have been studied in detail in terms of lithostratigraphy, high-resolution ammonite biostratigraphy and carbon stable isotopes. In addition to lithology, ammonite biostratigraphy and carbon isotopes, other data were also considered, such as the benthic macrofauna record (e.g. Paredes et al. 2013a, b) and the previously published total organic carbon values (see Duarte et al. 2012).

Biochronostratigraphy. - The new biochronostratigraphic determinations were based on the sampling and examination of more than 800 ammonite specimens. These data were complemented using other palaeontological information, e.g. the occurrence of benthic macrofauna (bivalves and brachiopods), recorded in the studied succession.

Carbon and oxygen stable isotopes in bulk carbonate. A total of 351 samples of bulk carbonate $\left(\delta^{13} \mathrm{C}_{\text {carb }}\right)$ were collected from the top of Coimbra Fm. and through the whole Água de Madeiros Fm. (Oxynotum to early Jamesoni chronozones interval). Approximately 275 of these samples are from an interval of $29 \mathrm{~m}$ in thickness, with a sampling spacing average of $10 \mathrm{~cm}$. The $\delta^{13} \mathrm{C}_{\text {carb }}$ and $\delta^{18} \mathrm{O}_{\text {carb }}$ measurements were performed in a stable isotope laboratory at Cardiff University, using a Thermo Electron Delta V Advantage mass spectrometer with an automated carbonate preparation device (GasBench III). The isotope values are presented in per mil relative to the PDB standard and calibrated using a routine preparation and analysis of the carbonate standard NBS-19. The analytical precision is generally better than $0.1 \%$ for both $\delta^{13} \mathrm{C}$ and $\delta^{18} \mathrm{O}$.

\section{Results}

\section{Lithostratigraphy and ammonite biochronostratigraphy}

\section{The Polvoeira Section}

This section is located at approximately $4 \mathrm{~km}$ south of

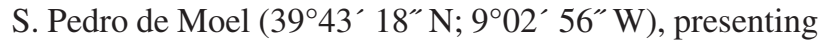
a continuous succession from the top of Coimbra Fm. to the middle-top part of the first member (Polvoeira Mb.) of

Figure 3. Lithostratigraphy, ammonite distribution, and main benthic faunal occurrences across the uppermost Sinemurian to lowermost Pliensbachian (Água de Madeiros Fm.) of S. Pedro de Moel composite section. Abbreviations: OXY - Oxynotum; RAR - Raricostatum; MAC - Macdonnelli; APL - Aplanatum; TAY - Taylori. 
Luís V. Duarte et al. - Carbon isotope stratigraphy and ammonite biochronostratigraphy across the Sinemurian-Pliensbachian boundary

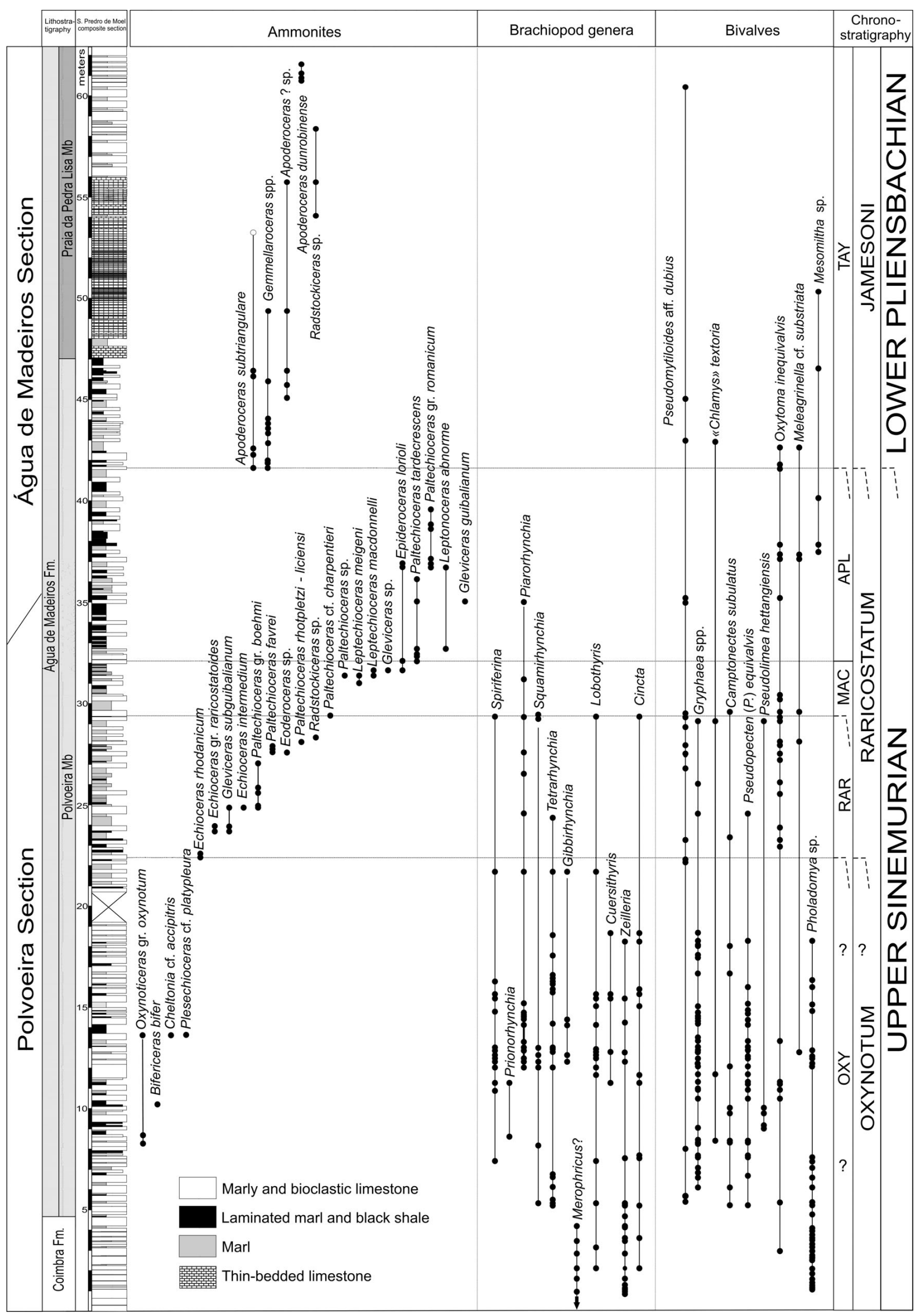


Água de Madeiros Fm. (Fig. 3). This locality is the only place where a continuous sedimentation between these two formations can be observed.

The Coimbra Fm. primarily comprises bioclastic limestone (wackestone to grainstone) and rare intercalations of greyish marl and bioclastic marlstone in excess of approximately $26 \mathrm{~m}$ (in Fig. 3 only the upper $4.5 \mathrm{~m}$ are illustrated). This part of the Coimbra Fm. is rich in benthic fauna, including brachiopods [primarily terebratulids, such as Merophricus? ribeiroi (Choffat) and Zeilleria quiaosensis (Choffat)], infaunal (e.g. Pholadomya) and epifaunal (Gryphaea) bivalves, gastropods and ahermatipic corals. Rhizocorallium and Thalassinoides trace fossils are particularly abundant and nektonic fossils are absent.

The Polvoeira Mb. (approximately $31 \mathrm{~m}$ thick) comprises organic-rich marl-limestone alternations, more bioclastic at the base, becoming progressively more argillaceous and rich in black shale in the uppermost part. Compared with the top of the Coimbra Fm., the base of the Polvoeira Mb. shows continuous deposition, with similar limestone facies and abundant and diversified macrofauna. Organic-rich facies occur in several levels, preferentially in marly beds, most of which exhibit fine lamination. The thickness of these beds is generally less than $10 \mathrm{~cm}$, with the thickest black shale level $(50 \mathrm{~cm})$ observed in the middle of the succession. This sedimentary variation is coupled with the occurrence of rare nektonic macrofossils, but some discrete levels with Oxynoticeras gr. oxynotum (Quenstedt), Bifericeras bifer (Quenstedt), Plesechioceras cf. platypleura Dommergues \& Meister and Cheltonia cf. accipitris (Buckman) have been identified (Figs 3 and 4A). In the upper part of this section the succession is more argillaceous (Fig. 4B) and enriched in organic matter (medium grey to dark grey marl, thin laminated limestone and black shale), coupled with an increase of nektonic invertebrate fauna (ammonites and belemnites), fossil fish and wood remains. Some levels are particularly rich in ammonites, such as oxynoticeratids and echioceratids, occurring in succession typical of the Raricostatum Chronozone: Echioceras rhodanicum (Dumortier), Echioceras gr. raricostatoides (Vadasz), Gleviceras subguibalianum (Pia), Paltechioceras gr. boehmi (Hug), Paltechioceras favrei (Hug), Paltechioceras rhotpletzi (Böse), Paltechioceras cf. charpentieri (Schafhautl), Leptechioceras meigeni (Hug), Leptechioceras macdonnelli (Portlock), Paltechioceras tardecrences (Hauer) (Fig. 4C), Gleviceras guibalianum (d'Orbigny) and Paltechioceras romanicum (Uhlig). The later three taxa occur abundantly in the upper studied level of the Polvoeira section (Fig. 4B).

As in the top of Coimbra Fm., benthic macrofauna (brachiopods and bivalves) are abundant in the lower portion of the Polvoeira Mb. Brachiopods are particularly abundant in the Oxynotum Chronozone, which include the Spiriferina genus, terebratulids (Lobothyris, Cuersithyris) and zeilleriids (Zeilleria, Cincta), while rhynchonellids and tetrarhynchiids dominate the assemblages (Tetrarhynchia, Squamirhynchia, Prionorhynchia, Gibbirhynchia, Piarorhynchia), with rhynchonellids becoming exclusive in the lower part of the Raricostatum Subchronozone. Among bivalves, Pholadomya and Gryphaea associations dominate up to the top of Oxynotum Chronozone. In the Raricostatum Chronozone, these associations are replaced by Pseudomytiloides aff. dubius Sowerby (Fig. 4D), and two different species of Oxytomidae, Oxytoma inequivalvis Sowerby and Meleagrinella aff. substriata (Münster), particularly in the upper part of Raricostatum Chronozone. Some Pectinoida are occasionally present, such as "Chlamys" textoria (Schlotheim), Camptonectes subulatus (Münster), Pseudopecten (Ps.) equivalvis Sowerby and Pseudolimea hettangiensis (Terquem).

\section{The Água de Madeiros Section}

The Água de Madeiros section is located approximately

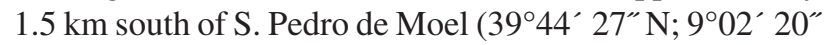
$\mathrm{W})$, and displays a continuous succession of approximately $30 \mathrm{~m}$ in thickness, including the top of Polvoeira and the Praia da Pedra Lisa members of Água de Madeiros Fm. (Figs 3, 4E, 4F). At the base, this section shows the upper part of the Polvoeira Mb., with marl-limestone alternations approximately $14 \mathrm{~m}$ thick, organic-rich levels (black shale) and wood fragments of decimetric sizes (see Silva et al. 2013). Marlstones are grey to black, occasionally laminated, and rich in disseminated organic matter, while limestone is generally in decimetric beds of fossiliferous wackestone, often with abundant ostracods and mollusks.

Belemnites and ammonites are particularly abundant in the lower part of the studied section, showing several levels with abundant Paltechioceras tardecrescens (Hauer), Paltechioceras romanicum (Uhlig), some Leptonoceras abnorme (Hauer) and Epideroceras lorioli (Hug), a typical ammonite association of the Raricostatum Chronozone (Aplanatum Subchronozone) (Fig. 4E).

Upwards, the top of Polvoeira Mb. shows a significant change in the ammonite record. After the disappearance of echioceratids (Fig. 4E), Gemmellaroceras spp. and Apoderoceras subtriangulare (Young \& Bird) appear marking the base of the Pliensbachian (see discussion below). Despite the relative abundance of ammonites in several levels, the specimens are tiny and/or poorly preserved. In the upper part of the Polvoeira Mb., brachiopods are practically absent and bivalves are restricted to sporadic occurrences of Mesomiltha sp., Oxytoma inequivalvis Sowerby and Meleagrinella aff. substriata (Münster).

The Praia da Pedra Lisa Mb. is predominantly calcareous (mainly mudstone and wackestone), beginning with approximately $9 \mathrm{~m}$ of decimetre- to centimetre-thick 

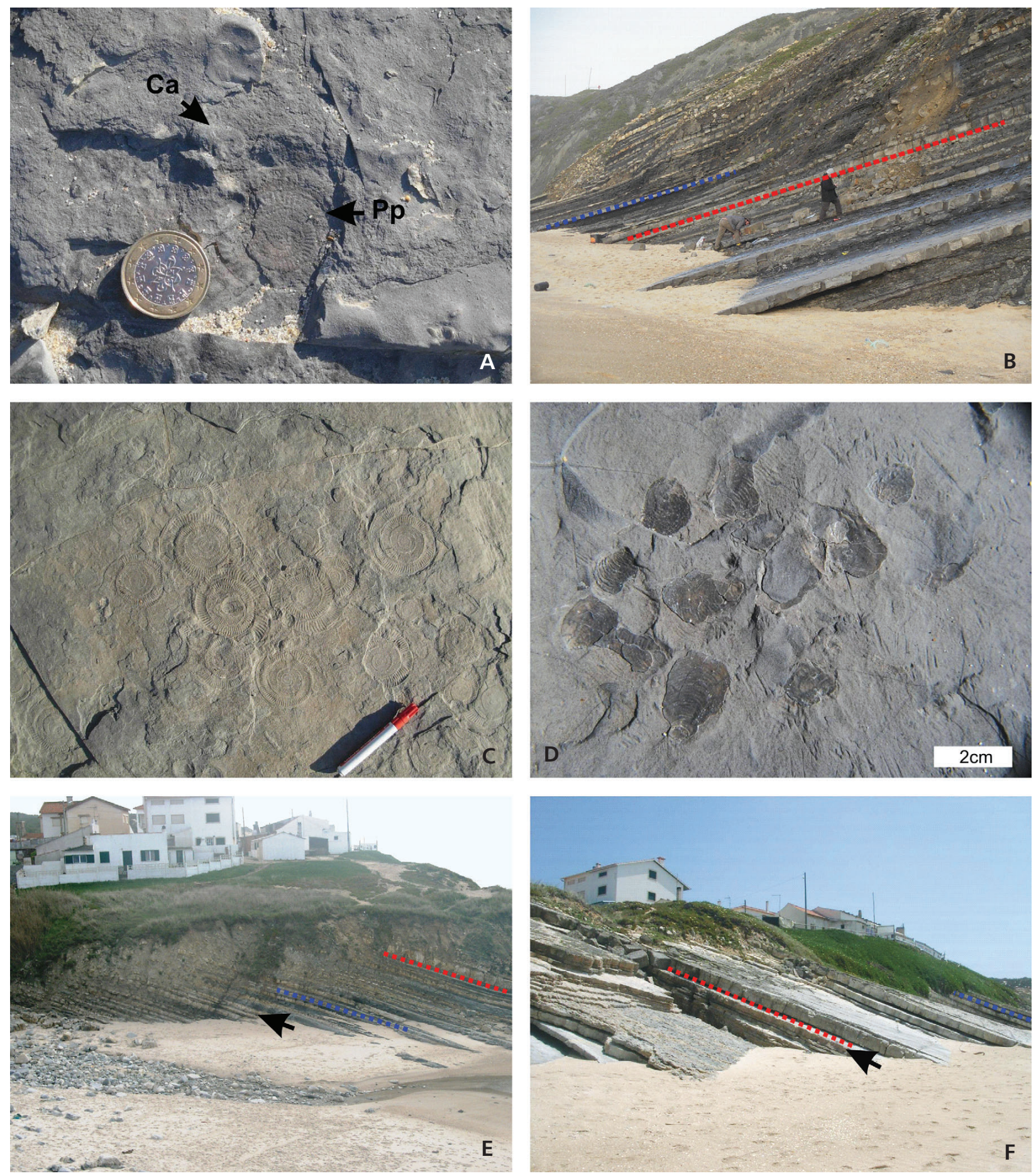

Figure 4. Biostratigraphically significant fossils and details of lithostratigraphy in the Oxynotum-Jamesoni chronozones interval (Água de Madeiros Fm.) in the studied area. $-A$ - Cheltonia cf. accipitris (Ca) and Plesechioeceras platypleura (Pp) recorded $\sim 13.7 \mathrm{~m}$ of the Polvoeira section (see Fig. 3). This ammonite association is typical of the Oxynotum Chronozone (Oxynotum Subchronozone). $\bullet$ B - upper part of the middle Polvoeira Mb. observed in the top of Polvoeira section. Red line: Raricostatum-Macdonnelli subchronozones boundary; blue line: Macdonnelli-Aplanatum subchronozones boundary. - $\mathrm{C}$ - bedding plane with abundant Paltechioceras tardecrescens (Aplanatum Subchronozone) observed in the Polvoeira section ( 32.5 m in the Fig. 3). - D - some slightly disarticulated Pseudomytiloides bivalves with preserved shell and showing the characteristic ornamental folds. Typical record of top of Raricostatum and base of Macdonnelli subchronozones from the Polvoeira section ( 29.4 m in the Fig. 3; Macdonellli Subchronozone). • E - lower part of the Água de Madeiros section showing the transition between the two members of the Água de Madeiros Fm. (red line). The arrow marks the uppermost level with echioceratids and the blue line corresponds to the first Apoderoceras subtriangulare (proposed Sinemurian-Pliensbachian boundary). $\bullet \mathrm{F}$ - middle-upper part of the Praia da Pedra Lisa Mb. in the Água de Madeiros section. Red line: change of facies observed in the middle part of the member (see text); arrow: reference level with Radstockiceras; blue line: first occurrence of Apoderoceras dunrobinense (according to Meister et al. 2012). 
microspar limestone, occasionally showing lamination and irregular stratification. Benthic and nektonic macrofauna are scarce; however, some levels yield tiny Gemmellaroceras sp. (?) and Radstockiceras sp. (Fig. 4F). Despite the occurrence of Rhizocorallium and Thalassinoides trace fossils, benthic macrofauna is practically absent.

The upper part of the studied member, approximately $7 \mathrm{~m}$ thick, is characterized by a gradual increase in interbedded centimetre-scale grey to dark grey marl and a marked thickening of the limestone beds. Some marly intervals show lamination, corresponding to organic-rich facies. Limestone consists of fossiliferous micrite to biomicrite/wackestone with mollusks and ostracods. Benthic macrofauna are rare, represented by the reappearance of Pseudomytiloides aff. dubius Sowerby and some disarticulated valves of Praechlamys rollei (Stoliczka), but belemnites and ammonites are occasionally identified in the limestone facies. Large specimens of Apoderoceras are frequent in the upper limestone levels of the member. Mouterde (1967b) and Antunes et al. (1981) assigned these levels to the Upper Sinemurian (Raricostatum Chronozone), but Duarte et al. (2010) suggested that these levels belong to Lower Pliensbachian (Jamesoni Chronozone, Taylori Subcronozone). This view was corroborated recently by Meister et al. (2012), who identified in these last levels the occurrence of Apoderoceras dunrobinense Spath, Tragophylloceras numismale (Quenstedt) and Vicininodiceras aff. mouterdei Donovan (Fig. 4F).

\section{Carbon and oxygen isotopes}

The $\delta^{13} \mathrm{C}_{\text {carb }}$ determined across the studied section shows a very large variation, between $-6.7 \%$ and $+2.85 \%$ (Fig. 5; and supplementary data table). The carbon isotope values generally decrease upward through the Polvoeira Mb., exhibiting the maximum values (above $+2 \%$ ) at the base of the studied succession (Oxynotum Chronozone). Strong negative values (below -2\%o) are exclusive to nine limestone beds recorded above the first occurrence of genus Echioceras (Raricostatum Subchronozone) until the top of the member. Across the boundary between the two members of the Água de Madeiros Fm., with the interruption of organic-rich facies in the succession, the $\delta^{13} \mathrm{C}_{\text {carb }}$ increases to approximately $+1 \%$ o. In addition to these general characteristics, other features in the carbon isotopic curve are notable (Fig. 5): 1) An important negative shift ( 1\%o) in the $\delta^{13} \mathrm{C}_{\text {carb }}$ from values clearly above $2 \%$ over the reference level with Bifericeras to values of approximately $1.5 \%$ o (between $\sim 10 \mathrm{~m}$ and $\sim 28 \mathrm{~m}$; see also Fig. 3). Despite this evolution some organic levels reach values below $0 \%$; 2) a negative shift is recorded around the levels with Paltechioceras tardecrences, Gleviceras guibalianum and Paltechioceras romanicum ( $32.5 \mathrm{~m}$; see also Fig. 3) showing values consistently below $1 \%$, with an average of $0.5 \%$; and 3 ) despite the increase in $\delta^{13} \mathrm{C}_{\text {carb }}$ at the base of the Praia da Pedra Lisa Mb. to values of approximately $+1 \%$, the carbon isotopic curve shows a slight decline across this member, after reaching a maximum value of $+1.34 \%$ o.

The oxygen isotope values in bulk carbonate $\left(\delta^{18} \mathrm{O}_{\text {carb }}\right)$ vary between $-5.61 \%$ and $-1.39 \%$. This variation across the studied succession of S. Pedro de Moel is clearly more irregular than that of the $\delta^{13} \mathrm{C}_{\text {carb }}$ values (Fig. 5). Besides the low correlation observed between $\delta^{18} \mathrm{O}_{\text {carb }}$ and $\delta^{13} \mathrm{C}_{\text {carb }}$ $\left(R_{2}=-0.25\right.$; Fig. 6$)$ there is a large contrast in the oxygen isotope signal between limestones and marls, and strong positive values are associated with most $\delta^{13} \mathrm{C}_{\text {carb }}$ negative ones. Despite these geochemical data, similar to $\delta^{13} \mathrm{C}_{\text {carb }}$, a large negative trend is also observed for the $\delta^{18} \mathrm{O}_{\text {carb }}$ of bulk carbonate across the Late Sinemurian.

\section{Discussion}

\section{Biochronostratigraphy}

The lithological equivalence, facies and ammonite record were used to establish a correlation between the two sections studied and present a detailed composite section for the uppermost Sinemurian to lowermost Pliensbachian in the $\mathrm{S}$. Pedro de Moel region. The studied formation is $58 \mathrm{~m}$ thick, with $42 \mathrm{~m}$ corresponding to the Polvoeira Mb. (Fig. 3). As previously demonstrated by Duarte et al. $(2010,2012)$ the most continuous succession corresponding to the uppermost Sinemurian-lower Pliensbachian is observed at S. Pedro de Moel, the only location within the basin presently well controlled by ammonites. Building on several studies concerning ammonites and the biostratigraphy of the Água de Madeiros section (e.g. Mouterde 1967b, Antunes et al. 1981, Meister et al. 2012), the data presented in this study provide a more detailed biostratigraphic resolution for the Oxynotum-Raricostatum chronozones interval, and new evidence for the Sinemurian-Pliensbachian boundary.

The ammonite record is facies dependent, showing scattered and isolated occurrences in the lower part of the Polvoeira and Praia da Pedra Lisa members (associated with shallower conditions; see Duarte et al. 2010), a fact that creates some uncertainties in the definition of some biochronostratigraphic boundaries. The taxa Oxynoticeras gr. oxynotum, Bifericeras bifer, Plesechioceras cf. platypleura and Cheltonia cf. accipitris at the base of the Polvoeira Mb. characterize the Oxynotum Chronozone (Oxynotum Subchronozone) (see Corna et al. 1997, Page 2003, Meister 2010), but the placement of the lower boundary of this Subchronozone is unknown. Despite the occurrence of several levels with ammonites from the Obtusum Chronozone (including endemic species of Epophio- 

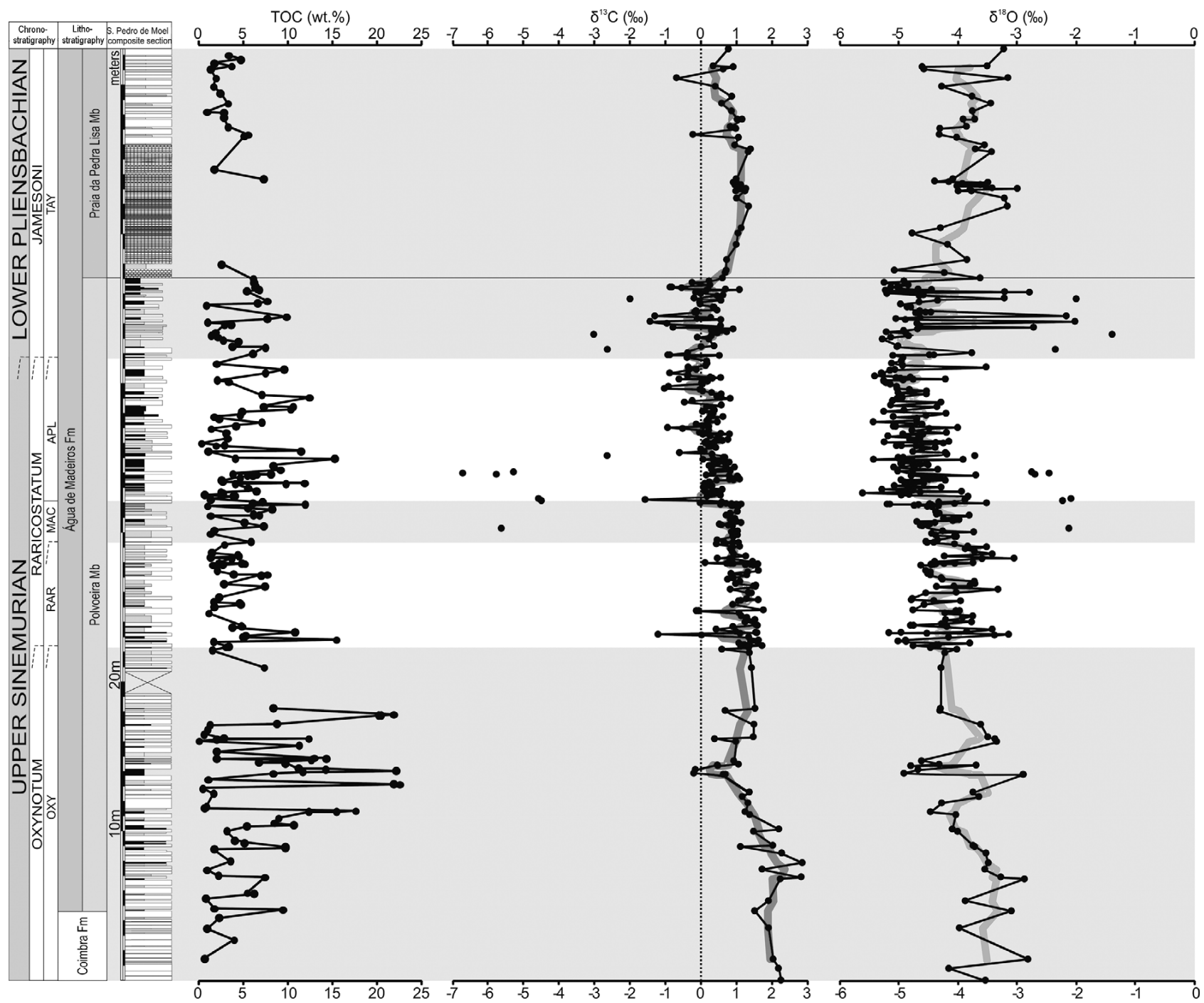

Figure 5. $\delta^{13} \mathrm{C}_{\text {carb }}$ evolution across the Oxynotum-earliest Jamesoni chronozone interval at S. Pedro de Moel. Variations in the TOC content from Duarte et al. (2012). Abbreviations: OXY - Oxynotum; RAR - Raricostatum; MAC - Macdonnelli; APL - Aplanatum; TAY - Taylori.

ceroides and Ptycharietites; Dommergues et al. 2010) observed in the middle part of Coimbra Fm. cropping out into the northern S. Pedro de Moel area (Concha beach and Penedo da Saudade; Figs 1B, 2), the base of the Oxynotum Chronozone is difficult to determine precisely in S. Pedro de Moel. Indeed, ammonites are absent in the bioclastic facies (wackestone-packestone) characterizing the upper part of the Coimbra Fm., which is more than 40 m thick. In addition, according to our knowledge about the lateral facies variation in the basin (dolostone dominates in the eastern part) and previously published data (see Mouterde et al. 1981), the fauna observed in the upper part of the Oxynotum Chronozone has not been identified in other locations within the LB.

The succession of taxa observed in the middle part of the Polvoeira Mb., with a great abundance of echioceratids and oxynoticeratids, facilitate the first detailed character- ization of the Raricostatum Chronozone in Portugal (Comas-Rengifo et al. 2013). The occurrence of Echioceras rhodanicum, Paltechioceras cf. charpentieri, Leptechioceras meigeni, Paltechioceras tardecrescens and Paltechioceras romanicum in a continuous succession, rich in ammonites (Fig. 3), allows the recognition of Raricostatum, Macdonnelli and Aplanatum subchronozones, respectively (see Corna et al. 1997, Blau \& Meister 2000, Page 2003, Meister 2010) (Figs 3, 4C, E). However, the absence of an ammonite record between the last horizon with Plesechioceras platypleura and Cheltonia cf. accipitris of the Oxynotum Subchronozone and the first occurrence of Echioceras species (in an interval more than $8 \mathrm{~m}$ thick) makes the definition of the Oxynotum-Raricostatum chronozone boundary uncertain and difficult the identification of index ammonites from the Densinodulum Subchronozone. 
Moreover, it has been difficult to define the base of the Pliensbachian Stage in S. Pedro de Moel area (e.g. Duarte et al. 2010, Meister et al. 2012), as is the case in other Tethyan and northwest European basins, due to the worldwide rarity of good sections with ammonites, frequent condensation, and endemism (Meister 2010). In the studied area, the absence of Bifericeras donovani Dommergues \& Meister, that allowed definition of the Pliensbachian GSSP (base of Jamesoni Chronozone) in Robin Hood's Bay (see Meister et al. 2003, 2006), the facies change between the two members of the Água de Madeiros Fm. and the scarcity of the ammonite record make it difficult to identify the early Jamesoni Chronozone index ammonites. According to the criteria of Meister (2010) for the LB, the Sinemurian-Pliensbachian boundary should be located between the last horizon with Paltechioceras and the first occurrence of Apoderoceras dunrobinense Spath, as Meister et al. (2012) recently identified in the Água de Madeiros section (Fig. 4F) corresponding to the lower part of the Jamesoni Chronozone (lower to middle Taylori Subchronozone). Based on the palaeontological information shown in Fig. 3, the interval of incertitude is approximately $19 \mathrm{~m}$ thick. However, based on our recent data, the occurrence of Apoderoceras subtriangulare (Figs 3, 4E) $2.2 \mathrm{~m}$ above the last level with echioceratids, represents the best marker for the definition of the base of the Jamesoni Chronozone. These levels with Apoderoceras and Gemmellaroceras, recorded in the uppermost part of the Polvoeira $\mathrm{Mb}$. and in some levels of the base of Praia da Pedra Lisa Mb., confirm an association very different from Apoderoceras dunrobinense identified by Meister et al. (2012) in the upper part of the studied section (see Figs 3, 4F). Moreover, based on the criteria of Meister (2010), the association of Apoderoceras with Gemmellaroceras in the Água de Madeiros section could be important for extrabasinal correlations. Indeed, these data are practically the same as those of Comas-Rengifo et al. (2010) in Asturias (northern Spain), which also show the absence of Bifericeras donovani. The recognition of Gemmellaroceras in several levels above the last occurrence of Paltechioceras tardecrescens in Asturias (see Comas-Rengifo et al. 2010), similar to S. Pedro de Moel, could be a good indicator in terms of biochronology of the lowermost Pliensbachian in Iberia.

\section{Interpretation of stable isotope data}

\section{Palaeoenvironmental interpretation and diagenesis}

The studied carbonate succession is dominated by marllimestone alternations with significant organic matter accumulation, materialized in high TOC (Fig. 5), a charac- teristic exclusive to the western portion of the LB and particularly well developed in the studied area (Duarte et al. 2012). As demonstrated by Duarte et al. (2010), these organic-rich facies disappear laterally in the Upper Sinemurian (Fig. 1C) and in the eastern part of the basin the series are dominated by dolostone and dolomitic limestone. The role of organic matter is important in the palaeoenvironmental discussion and the vertical variation of $\delta^{13} \mathrm{C}_{\text {carb }}$ recorded at S. Pedro de Moel.

At S. Pedro de Moel, the benthos-rich fossil community is associated with calcareous facies in the Oxynotum Chronozone, suggesting a palaeoenvironment dominated by shallow marine conditions with normal oxygen levels. This carbonate-rich sedimentation was interrupted by some phases of organic accumulation, in centimetric black shale intervals, reaching up to $22 \mathrm{wt}$ \% TOC (Fig. 5; Duarte et al. 2012). Despite the high abundance of benthic macrofossils, including endobenthonics such as Pholadomya, this group is absent in TOC-rich levels (above 4 wt.\%), suggesting dysoxic (perhaps anoxic) phases. The kerogen type described in several samples from the Oxynotum Chronozone by Duarte et al. (2012) and Poças Ribeiro et al. (2013) indicates some palaeoenvironmental restriction, with a clear dominance of amorphous organic matter and a low contribution of palynomorphs and phytoclasts. In this context, the carbon isotope signal observed in this part of the succession, sometimes above $+2 \%$, is typical of a normal marine environment. The secular negative trend observed in the top of Oxynotum Chronozone is clearly influenced by the increase of organic matter of black shales in this part of the succession, such as confirmed by the TOC curve (Fig. 5).

The sedimentary conditions changed significantly in the Raricostatum to base of the Jamesoni chronozones interval. Indeed, an increase in clay is observed in the succession from the Raricostatum Subchronozone, together with enhanced organic-rich deposition, better developed than that in the Oxynotum Subchronozone (despite the fact that highest values above 20 wt.\% here observed), confirmed through the high TOC content through multiple levels (Fig. 5). According to Duarte et al. (2012) the TOC background in the marly facies of upper Sinemurian to lowermost Pliensbachian interval is generally greater than $2 \mathrm{wt} . \%$, with several (thicker) levels near $10 \mathrm{wt}$. $\%$. In addition, the kerogen assemblages are rich in amorphous organic matter through the upper part of the Polvoeira Mb. (Raricostatum-extreme base of Jamesoni chronozones interval), but a slight increase in palynomorphs and phytoclasts is observed (see Duarte et al. 2012). Moreover, the succession (Raricostatum Chronozone) becomes enriched in nektonic fauna (principally ammonites, with occurrence of the first echioceratids, and belemnites), while the benthic fossil content abruptly decreases. An exception is an interesting fauna of Pseudomytiloides and Oxytoma 
inequivalvis (Paredes et al. 2013a, b), a fauna that has been associated with oxygen-deficient waters of northwestern European Early Toarcian (e.g. Schmid-Rohl et al. 2002, Wignall et al. 2005, Caswell et al. 2009). Thus, the sedimentary evidence identified in the Raricostatum Chronozone is correlated with a major transgressive event, observed in other points of the basin, such as Peniche, Figueira da Foz and Montemor-o-Velho (Fig. 1A; see Duarte et al. 2010). In this sedimentary context, we observe a drop in $\delta^{13} \mathrm{C}_{\text {carb }}$, compared with the previous Oxynotum Chronozone (Fig. 5). A slight negative carbon-isotope trend is evident across the Polvoeira Mb., i.e., between the Oxynotum Subchronozone and the earliest Jamesoni Chronozone. In addition to the negative trend of carbon-isotope curve, strongly anomalous negative $\delta^{13} \mathrm{C}_{\text {carb }}$ values (between -7 and $-2 \%$ ) have been recorded in several carbonate-enriched horizons, which are poor in TOC (calcareous facies with TOC $<1 \mathrm{wt} . \%$ ). Considering the organic rich-facies dominance of this part of the succession, including the entire Raricostatum Chronozone, these sudden variations are likely associated with the oxidation of organic matter responsible for the occurrence of isotopically light dissolved inorganic carbon at the sea floor (e.g. von Breymann et al. 1991, Marshall 1992). In addition, sedimentological data suggest that the limestone underwent diagenetic effects, such as rapid lithification and early cementation. Indeed, lighter carbon isotope values, corresponding to highest oxygen isotopic values, have been observed in non-compacted limestone lithotypes, evidenced in some beds through taphonomic criteria, such as the preserved volume of ammonite shells, filled with calcite spar cements (see Duarte et al. 2004b). Silva et al. (2011) discussed similar features as observed in the $\delta^{13} \mathrm{C}_{\text {carb }}$ record of the Pliensbachian (Ibex-Margaritatus chronozones) marllimestone series at Peniche. It is possible that early cementation, associated with the microbial processes of organic matter decay and/or marine cementation, might have been the cause for the observed scatter of $\delta^{13} \mathrm{C}$ data (Silva et al. 2011 and references therein). These geochemical anomalies, observed through the Raricostatum Chronozone, are clearly controlled by diagenesis, showing the complexity of the geochemical processes associated with organic matter and carbonate deposition.

The major change in the sedimentation occurred with the deposition of limestone corresponding to the base of the Praia da Pedra Lisa Mb. This vertical change, characterized by the abrupt disappearance of clay and organic matter, is particularly evident in other parts of the basin, suggesting that a regressive event occurred in the LB during the earliest Pliensbachian. The $\delta^{13} \mathrm{C}_{\text {carb }}$ values stabilized across the calcareous facies of this member, showing values around $+1 \%$. However, the slight negative trend of carbon isotopes observed in the top of the studied succession (Fig. 5) might reflect an increase in organic

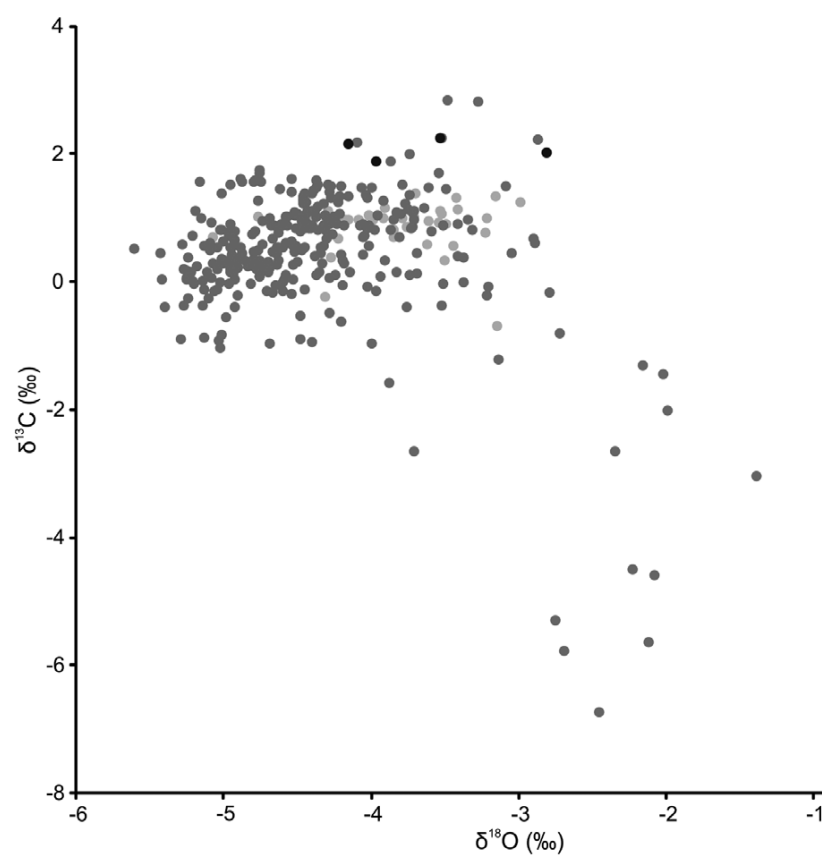

Figure 6. Cross plot of $\delta^{13} \mathrm{C}_{\text {carb }}$ and $\delta^{18} \mathrm{O}_{\text {carb }}$ from the Oxynotum-earliest Jamesoni chronozone interval at S. Pedro de Moel. - Praia da Pedra Lisa Mb., - Polvoeira Mb., - Coimbra Formation.

matter, confirmed by the TOC curve of Duarte et al. (2012).

\section{Global isotope events in the Late Sinemurian and at the Sinemurian/Pliensbachian boundary?}

The Lower Jurassic marly limestones of the LB have been the focus of several studies associated with stable isotope geochemistry and chemostratigraphy (e.g. Duarte et al. 2004a, 2007; Oliveira et al. 2006, 2009; Hesselbo et al. 2007; Suan et al. 2008a, 2010; Silva et al. 2011, 2013; Pittet et al. 2014). Some of these studies were based on high-resolution data obtained from bulk carbonate, brachiopods, belemnites, bulk organic matter, and fossil wood, generated in the context of an accurate ammonite biostratigraphy. Concerning carbon isotopes, several geochemical events have been identified in the Pliensbachian-Toarcian interval of the basin, particularly those in association with the Toarcian Oceanic Anoxic Event (T-OAE) (e.g. Hesselbo et al. 2007; Suan et al. 2008a, b, 2010; Littler et al. 2010; Pittet et al. 2014).

Considering the Sinemurian record and the Sinemurian-Pliensbachian boundary, this interval has not yet been sufficiently studied and clarified in terms of stable isotopes, despite the significant contributions of Hesselbo et al. (2000), Jenkyns et al. (2002), Morettini et al. (2002), van de Schootbrugge et al. (2005), Korte \& Hesselbo (2011), Riding et al. (2013) and Jenkyns \& Weedon (2013). Consistent with different parameters and 


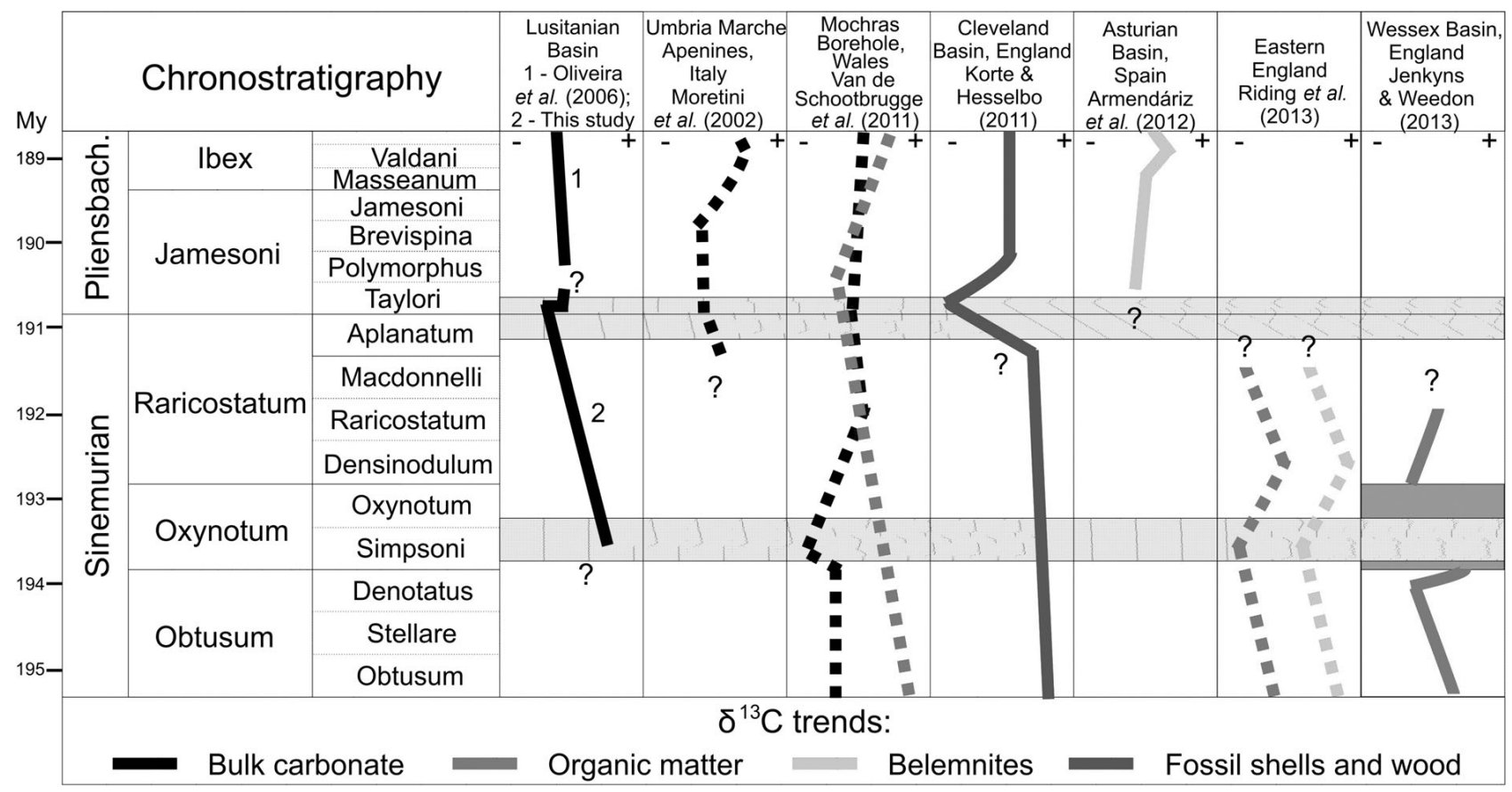

Figure 7. Correlation of the bulk carbonate C-isotope curve from Portugal and other C-isotope secular trends from other European basins across the Sinemurian-Pliensbachian boundary. Ammonite chronostratigraphy data from Ogg \& Hinnov (2012). Continuous lines: high-resolution analysis; dashed lines: low-resolution analysis. Dark gray shading: hiatus; light gray shading indicates the two global C-isotopic events suggested by Riding et al. (2013) (Oxynotum Chronozone) and Korte \& Hesselbo (2011) (Sinemurian-Pliensbachian boundary).

stratigraphic resolutions, Riding et al. (2013) and Korte \& Hesselbo (2011) recently reported two negative carbon-isotope excursions from the Oxynotum Chronozone and at the Sinemurian-Pliensbachian boundary, respectively (Fig. 7). The last one was evidenced, for the first time, by Jenkyns et al. (2002), based on scattered belemnite data from Central and Western Europe. From a large data set of analyzed materials (belemnites, bivalves, brachiopods and fossil wood fragments) across the base Pliensbachian GSSP at Robin Hood's Bay, England (Fig. 7; see also Hesselbo et al. 2000, Meister et al. 2006), Korte \& Hesselbo (2011) demonstrated a drop of $\sim 2 \%$ in the carbon-isotope record around the cited boundary, interpreted by these authors as a major carbon isotope event, similar to that observed in the Early Toarcian (Polymorphum-Levisoni Chronozone boundary).

Although the Oxynotum negative carbon isotope excursion is not corroborated by our results, perhaps due to the absence of isotopic data below the Oxynotum Chronozone, a negative carbon-isotope trend (greater than 2.5\%o; Fig. 5) is observed in the S. Pedro de Moel section, in bulk carbonates between the Oxynotum Chronozone and the first levels with Gemmellaroceras and Apoderoceras (indicators of earliest Pliensbachian). This chemostratigraphic event seems to be correlative with $\delta^{13} \mathrm{C}$ negative excursion recorded at Robin Hood's Bay (see Korte \& Hesselbo 2011; Fig. 7). However, no sudden negative ex- cursion is recorded in the Portuguese series, unlike observed at Robin Hood's Bay. At S. Pedro de Moel, the $\delta^{13} \mathrm{C}_{\text {carb }}$ curve shows a slight increase across the levels with Radstockiceras sp. and Apoderoceras dunrobinense (Taylori Subchronozone; see Meister et al. 2012), with values around $+1 \%$ o (Fig. 5). This trend precedes a slight drop in $\delta^{13} \mathrm{C}_{\text {carb }}$, observed across the Jamesoni Chronozone in the carbon isotopic data presented by Oliveira et al. (2006) for the Pliensbachian of the Peniche reference section (Fig. 7). At a regional scale, although examples of high-resolution stratigraphic analysis are limited (exception of Korte \& Hesselbo 2011, Armendáriz et al. 2012), the early Pliensbachian carbon isotope evolution recorded in the LB is not consistent with those observed in Northern Spain (Asturian and Basque-Cantabrian basins), Central Italy (Umbria-Marches Apeninnes) or England (e.g. Morettini et al. 2002, van de Schootbrugge et al. 2005, Rosales et al. 2006, Korte \& Hesselbo et al. 2011, Armendáriz et al. 2012), particularly during the Ibex Chronozone, as presented in Fig. 7 (see also Silva et al. 2011).

Considering the sedimentary characteristics of the studied succession, which comprises different carbonate units with several lateral and vertical facies changes, the $\delta^{13} \mathrm{C}_{\text {carb }}$ curve across the Sinemurian-Pliensbachian of S. Pedro de Moel is strongly influenced by the role of organic matter during sedimentation. Similarly to the case documented recently by Jenkyns \& Weedon (2013) for Southwest England, the re- 
gional occurrence of organic matter around the western and northern Iberia Peninsula during the Late Sinemurian to Early Pliensbachian (see Duarte et al. 2010, 2012, and references therein) could be an important factor in the control of the global seawater carbon-isotope composition.

\section{Conclusions}

In the LB, the Sinemurian comprises thick carbonate deposits, showing great lateral facies differentiation from eastern dolostones and dolomitic limestones to western distal ramp limestones and marly limestones. In this region of the basin, the Upper Sinemurian (Oxynotum-Raricostatum chronozones) is characterized by organic-rich facies with a good record of ammonites. The S. Pedro de Moel composite section constitutes the most continuous and biostratigraphically well constrained succession in the basin for the Upper Oxynotum Chronozone to the Lower Jamesoni Chronozone. The following conclusions are derived from the high-resolution stratigraphic analysis of this reference section in terms of ammonite biochronostratigraphy and carbon isotope evolution:

1) A detailed ammonite biostratigraphic characterization of the Oxynotum and Raricostatum chronozones (and subchronozones) is presented for the first time in the LB, supported by a high-resolution bed-by-bed sedimentological and geochemical (TOC) analysis of the succession. The occurrence of Apoderoceras $\sim 2.2 \mathrm{~m}$ above the last Paltechioceras level allows precise the identification of the Sinemurian-Pliensbachian boundary.

2) Across the Oxynotum to lowermost Jamesoni chronozones the carbon isotope data from bulk carbonate show a significant negative trend (from values of $+2.85 \%$ o to around $0 \%$ ), with very negative values (between $-2 \%$ o and $-6.7 \%$ ) recorded particularly in some calcareous levels of the Raricostatum to earliest Jamesoni chronozones. The isotopic signal is clearly correlated with facies changes, and the most negative values are particularly influenced by organic matter in the depositional environment. However, despite these sedimentary characteristics, the negative trend of $\delta^{13} \mathrm{C}_{\text {carb }}$ ended in the earliest Pliensbachian, showing similarities to the negative carbon isotope excursion recently identified in the Cleveland Basin.

3) In the present study, using the most recent data obtained in the S. Pedro de Moel region, we emphasize the importance of this area as the main stratigraphic reference of the Sinemurian in the whole western Iberia margin. Considering the organic nature of the sedimentation, all these geochemical trends would be confirmed through the carbon isotope analyses in bulk organic matter, to develop in a future work.

\section{Acknowledgements}

This work has been financially supported by project PTDC/CTE-GIX/098968/2008 - "High resolution stratigraphy of the Lower Jurassic organic-rich marine series in the Lusitanian Basin" (FCT-Portugal and COMPETE-FEDER) and CGL2011-25894 (Ministry of Science and Technology, Spanish Government). We thank S. Hesselbo and J. Palfy for their useful comments that improve the final version of this manuscript.

\section{References}

Alves, T.M., Gawthorpe, R.L., Hunt, D.W. \& Monteiro, J.H. 2002. Jurassic tectono-sedimentary evolution of the Northern Lusitanian Basin (offshore Portugal). Marine and Petroleum Geology 19, 727-754. DOI 10.1016/S0264-8172(02)00036-3

Antunes, M.T., Rocha, R.B. \& Wenz, S. 1981. Faunule ichtyologique du Lias inférieur de São Pedro de Moel, Portugal. Ciências da Terra 6, 101-116.

Armendáriz, M., Rosales, I., Bádenas, B., Aurell, M., García-Ramos, J.C. \& Piñuela, L. 2012. High resolution chemostratigraphic records from Lower Pliensbachian belemnites: Palaeoclimatic perturbations, organic facies and water mass exchange (Asturian Basin, northern Spain). Palaeogeography, Palaeoclimatology, Palaeoecology 333-334, 178-191. DOI 10.1016/j.palaeo.2012.03.029

Azerêdo, A.C., Duarte, L.V., Henriques, M.H. \& Manuppella, G. 2003. Da dinâmica continental no Triásico aos mares do Jurássico Inferior e Médio. 43 pp. Cadernos de Geologia de Portugal. Instituto Geológico e Mineiro, Lisbon.

Azerêdo, A.C., Silva, R.L., Duarte, L.V. \& Cabral, M.C. 2010. Subtidal stromatolites from the Sinemurian of the Lusitanian Basin (Portugal). Facies 56, 211-230.

DOI 10.1007/s10347-009-0198-0

Blau, J. \& Meister, C. 2000. Upper Sinemurian ammonite successions based on 41 faunal horizons: an attempt at worldwide correlations. GeoResearch Forum 6, 3-12.

Caswell, B.A., Coe, A.L. \& Cohen, A.S. 2009. New range data for marine invertebrate species across the early Toarcian (Early Jurassic) mass extinction. Journal of the Geological Society of London 166, 859-872. DOI 10.1144/0016-76492008-0831

Choffat, P. 1903-1904. L'Infralias et le Sinémurien au Portugal. Comunicações do Instituto Geológico e Mineiro Portugal 5, 49-114.

Comas-Rengifo, M.J., Duarte, L.V., Goy, A., Paredes, R. \& Silva, R.L. 2013. El Sinemuriense Superior (cronozonas Oxynotum y Raricostatum) en la región de S. Pedro de Moel (Cuenca Lusitánica, Portugal), 15-19. In DuARte, L.V., Silva, R.L. \& AzeręDo, A.C. (eds) Fácies carbonatadas ricas em matéria orgânica do Jurássico da Bacia Lusitânica. Novos contributos paleontológicos, sedimentológicos e geoquímicos. Comunicações Geológicas 100, Especial I.

Comas-Rengifo, M.J., Martínez, J.C. \& Goy, A. 2010. Sinemuriense Superior en Rodiles (Asturias): Biocronoestratigrafía y biohorizontes de ammonoideos, 49-56. In Ruíz-Omeñaca, J.I., Piñuela, L. \& García-Ramos, L.C. (eds) Comunicaciones del $V$ Congreso del Jurásico de España. Museo del Jurásico de Asturias (MUJA). 
Corna, M., Dommergues, J.-L., Meister, C. \& Mouterde, R. 1997. Sinemurien, 9-14. In CARiou, E. \& HantzPergue, P. (eds) Biostratigraphie du Jurassique ouest-européen et méditerranéen: zonations paralleles et distribution des invertebres et microfossiles, Groupe français d'Etude du Jurassique. Bulletin des Centres de Recherche Exploration-Production Elf-Aquitaine 17.

Correia, G., Duarte, L.V., Pereira, A. \& Silva, R.L. 2012. Outcrop Spectral Gamma-Ray applications to the SinemurianPliensbachian organic-rich facies of the Lusitanian Basin (Portugal). Journal of Iberian Geology 38(2), 373-388.

Dommergues, J.-L. 1987. L'évolution chez les Ammonitina du Lias moyen (Carixien, Domérien basal) en Europe occidentale. Documents des Laboratoires de Géologie Lyon 98, 1-87.

Dommergues, J.-L., Meister, C., Neige, P. \& Rocha, R.B. 2004. Endemic Sinemurian (Early Jurassic) ammonites from the Lusitanian Basin (Portugal). Revue de Paléobiologie 23, 529-549.

Dommergues, J.-L., Meister, C. \& Rocha, R.B. 2010. The Sinemurian ammonites of the Lusitanian Basin (Portugal): an example of complex endemic evolution. Paleodiversity 3, 59-87.

DUARTE, L.V. 2007. Lithostratigraphy, sequence stratigraphy and depositional setting of the Pliensbachian and Toarcian series in the Lusitanian Basin (Portugal), 17-23. In Rocha, R.B. (ed.) The Peniche section (Portugal). Contributions to the definition of the Toarcian GSSP. International Subcommission on Jurassic Stratigraphy.

Duarte, L.V., Oliveira, L.C.V. \& Rodrigues, R. 2007. Carbon isotopes as a sequence stratigraphic tool: examples from the Lower and Middle Toarcian marly limestones of Portugal. Boletín Geológico y Minero 118, 3-17.

Duarte, L., Perilli, N., Dino, R., Rodrigues, R. \& Paredes, R. 2004a. Lower to Middle Toarcian from the Coimbra region (Lusitanian Basin, Portugal): sequence stratigraphy, calcareous nannofossils and stable-isotope evolution. Rivista Italiana di Paleontologia e Stratigrafia 110, 115-127.

Duarte, L.V., Silva, R.L., Duarte, C.B., Azerêdo, A.C. \& Comas-Rengifo, M.J. 2008. Litostratigrafia do Jurássico Inferior da região de S. Pedro de Moel (Bacia Lusitânica), 175-185. In Callapez, P.M., Rocha, R. B., Marques, J.F., Cunha, L.S. \& Dinis, P.M. (eds) A Terra, Conflitos e Ordem. Homenagem ao Professor Ferreira Soares, Museu e Laboratório de Mineralogia e Geologia da Universidade de Coimbra.

Duarte, L.V., Silva, R.L., Mendonça Filho, J.G., Poças Ribeiro, N. \& Chagas, R.B.A. 2012. High-resolution stratigraphy, palynofacies and source rock potential of the Água de Madeiros Formation (Upper Sinemurian) of the Lusitanian Basin, Portugal. Journal of Petroleum Geology 35, 105-126. DOI 10.1111/j.1747-5457.2012.00522.x

Duarte, L.V., Silva, R.L., Oliveira, L.C.V., Comas-Rengifo, M.J. \& Silva, F. 2010. Organic-rich facies in the Sinemurian and Pliensbachian of the Lusitanian Basin, Portugal: Total Organic Carbon distribution and relation to transgressive-regressive facies cycles. Geologica Acta 8, 325-340.

DuArte, L.V. \& SoAres, A.F. 2002. Litostratigrafia das séries margo-calcárias do Jurássico Inferior da Bacia Lusitânica (Portugal). Comunicações do Instituto Geológico e Mineiro 89, 135-154.

Duarte, L.V., Wright, V.P., Fernández-López, S.F., Elmi, S., Krautter, M., Azerêdo, A.C., Henriques, M.H., Rodrigues,
R. \& PerilLi, N. 2004b. Early Jurassic carbonate evolution in the Lusitanian Basin (Portugal): facies, sequence stratigraphy and cyclicity, 45-71. In Duarte, L.V. \& Henriques, M.H. (eds) Carboniferous and Jurassic Carbonate Platforms of Iberia. $23^{\text {rd }}$ IAS Meeting of Sedimentology Field Trip Guide Book, Coimbra, Vol. 1.

Hesselbo, S.P., Jenkyns, H.C., Duarte, L.V. \& Oliveira, L.C.V. 2007. Carbon-isotope record of the Early Jurassic (Toarcian) Oceanic Anoxic Event from fossil wood and marine carbonate (Lusitanian Basin, Portugal). Earth and Planetary Science Letters 253, 455-470.

DOI 10.1016/j.epsl.2006.11.009

Hesselbo, S.P., Meister, C. \& Gröcke, D.R. 2000. A potential global stratotype for the Sinemurian-Pliensbachian boundary (Lower Jurassic), Robin Hood's Bay, UK: ammonite faunas and isotope stratigraphy. Geological Magazine 137(6), 601-607. DOI 10.1017/S0016756800004672

Jenkyns, H.C., Jones, C.E., Gröcke, D.R., Hesselbo, S.P. \& PARKINSON, D.N. 2002. Chemostratigraphy of the Jurassic System: applications, limitations and implications for palaeoceanography. Journal of the Geological Society of London 159, 351-378. DOI 10.1144/0016-764901-130

Jenkyns, H.C. \& WeEdon, G. 2013. Chemostratigraphy $\left(\mathrm{CaCO}_{3}\right.$, TOC, $\delta^{13} \mathrm{C}_{\text {org }}$ ) of Sinemurian (Lower Jurassic) black shales from the Wessex Basin, Dorset and palaeonvironmental implications. Newsletters on Stratigraphy 46(1), 1-21. DOI 10.1127/0078-0421/2013/0029

Korte, C. \& Hesselbo, S.P. 2011. Shallow-marine carbon- and oxygen-isotope and elemental records indicate icehousegreenhouse cycles during the Early Jurassic. Paleoceanography 26, PA4219. DOI 10.1029/2011PA002160

Littler, K., Hesselbo, S.P. \& Jenkyns, H.C. 2010. A carbon-isotope perturbation at the Pliensbachian-Toarcian boundary: evidence from the Lias Group, NE England. Geological Magazine 147, 181-192. DOI 10.1017/S0016756809990458

Marshall, J.D. 1992. Climatic and oceanographic isotopic signalsnfrom carbonate rock record and their preservation. Geological Magazine 192, 143-160. DOI 10.1017/S0016756800008244

Mattioli, E., PlancQ, M., Boussaha, M., Duarte, L.V. \& Pittet, B. 2013. Calcareous nannofossil biostratigraphy: new data from the Early Jurassic of the Lusitanian Basin, 69-76. In DuARTE, L.V., Silva, R.L. \& Azerêdo, A.C. (eds) Fácies carbonatadas ricas em matéria orgânica do Jurássico da Bacia Lusitânica. Novos contributos paleontológicos, sedimentológicos $e$ geoquímicos. Comunicações Geológicas 100, Especial I.

Meister, C. 2010. Worldwide ammonite correlation at the Pliensbachian Stage and Substage Boundaries (Lower Jurassic). Stratigraphy 7, 83-101.

Meister, C., Aberhan, C., Blau, J., Dommergues, J.-L., Feist-Burkhardt, S., Hailwood, E.A., Hart, M., Hesselbo, S.P., Hounslow, M.W., Hylton, M., Morton, N., Page, K. \& PrICE, G.D. 2006. The Global Boundary Stratotype Section and Point (GSSP) for the base of the Pliensbachian Stage (Lower Jurassic), Wine Haven, Yorkshire, UK. Episodes 29(2), 93-106.

Meister, C., Blau, J., Dommergues, J.L., Feist-Burkhardt, S., Hart, M., Hesselbo, S.P., Hylton, M., Page, K. \& Price, G. 2003. A proposal for the Global Boundary Stratotype Section 
and Point (GSSP) for the base of the Pliensbachian Stage (Lower Jurassic). Eclogae Geologicae Helvetiae 96, 275-297.

Meister, C., Dommergues, J.-L. \& Rocha, R.B. 2012. Ammonites from the Apoderoceras beds (Early Pliensbachian) in São Pedro de Muel (Lusitanian Basin, Portugal). Bulletin of Geosciences 87(3), 407-430.

DOI 10.3140/bull.geosci.1325

Morettini, E., Santantonio, M., Bartolini, A., Cecca, F., Baumgartner, P.O. \& HunziKer, J.C. 2002. Carbon-isotope stratigraphy and carbonate production during the Early-Middle Jurassic: examples from the Umbria-Marche-Sabina Apennines (central Italy). Palaeogeography, Palaeoclimatology, Palaeoecology 184, 251-273.

DOI 10.1016/S0031-0182(02)00258-4

Mouterde, R. 1967a. Le Lias du Portugal. Vue d'ensemble et division en zones. Comunicações dos Serviços Geológicos de Portugal 52, 209-226.

Mouterde, R. 1967b. Le Lias moyen de S. Pedro de Muel (Portugal). Comunicações dos Serviços Geológicos de Portugal 52, 185-208.

Mouterde, R., Rocha, R.B. \& Delance, J. 1981. Atlas des fossiles caractéristiques du Lias portugais. Ciências da Terra $6,49-76$.

OGG, J.G. \& Hinnov, L.A. 2012. Jurassic, 731-791. In GraDStein, F.M., OGG, J.G., Schmitz, M.D. \& OGG, G. (eds) The Geologic Time Scale 2012. Elsevier, Oxford, Amsterdam, Waltham.

Oliveira, L.C., Duarte, L.V., Lemos, V.B., Comas-Rengifo, M.J. \& PERILLI, N. 2007. Bioestratigrafia de nanofósseis calcários e correlação com as zonas de amonites do Pliensbaquiano-Toarciano basal (Jurássico inferior) de Peniche (Bacia Lusitânica, Portugal). Actas do XIX Congresso Brasileiro de Paleontologia, Búzios (Brasil), Editora Interciência, 411-420.

Oliveira, L.C., Duarte, L.V., Silva, R.L. \& Rodrigues, R. 2009. Belemnite $\delta^{18} \mathrm{O}$ and $\delta^{13} \mathrm{C}$ record of the Lusitanian Basin Pliensbachian carbonate series (Portugal). Geochimica et Cosmochimica Acta 73, A969 (abstract).

Oliveira, L.C., Rodrigues, R., Duarte, L.V. \& Lemos, V. 2006. Avaliação do potencial gerador de petróleo e interpretação paleoambiental com base em biomarcadores e isótopos estáveis do carbono da seção Pliensbaquiano-Toarciano inferior (Jurássico inferior) da região de Peniche (Bacia Lusitânica, Portugal). Boletim de Geociências da Petrobras 14(2), 207-234.

PAGE, K.N. 2003. The Lower Jurassic of Europe: its subdivision and correlation. Geological Survey of Denmark and Greenland Bulletin 1, 23-59

Paredes, R., Comas-Rengifo, M.J. \& Duarte, L.V. 2013a. Moluscos bivalves da Formação de Água de Madeiros (Sinemuriano Superior) da Bacia Lusitânica (Portugal), 21-27. In DuARTE, L.V., Silva, R.L. \& AzERÊDo, A.C. (eds) Fácies carbonatadas ricas em matéria orgânica do Jurássico da Bacia Lusitânica. Novos contributos paleontológicos, sedimentológicos e geoquímicos. Comunicações Geológicas 100, Especial I.

Paredes, R., Comas-Rengifo, M.J., Duarte, L.V. \& Goy, A. 2013b. Braquiópodes do Sinemuriano superior da região de S. Pedro de Moel e de Peniche (Bacia Lusitânica, Portugal), 29-35. In Duarte, L.V., Silva, R.L. \& Azerêdo, A.C. (eds) Fácies carbonatadas ricas em matéria orgânica do Jurássico da Bacia Lusitânica. Novos contributos paleontológicos, sedimentológicos e geoquímicos. Comunicações Geológicas 100, Especial I.

Phelps, M. 1985. A refined ammonite biostratigraphy for the Middle and Upper Carixian (ibex and davoei zones, Lower Jurassic) in North-West Europe and stratigraphical details of the Carixian-Domerian boundary. Geobios 18, 321-362. DOI 10.1016/S0016-6995(85)80098-X

Pittet, B., Suan, G., Lenoir, F., Duarte, L.V. \& Mattioli, E. 2014. Carbon isotope evidence for sedimentary discontinuities in the lower Toarcian of the Lusitanian Basin (Portugal): Sea level change at the onset of the Oceanic Anoxic Event. Sedimentary Geology 303, 1-14. DOI 10.1016/j.sedgeo.2014.01.001

Poças Ribeiro, N., Mendonça Filho, J.G., Duarte, L.V., Silva, R.L., Mendonça, J.O. \& Silva, T.F. 2013. Palynofacies and organic geochemistry of the Sinemurian carbonate deposits in the western Lusitanian Basin (Portugal): Coimbra and Água de Madeiros formations. International Journal of Coal Geology 111, 37-52. DOI 10.1016/j.coal.2012.12.006

POMPECKJ, J.F. 1898. Note sur quelques ammonites du Sinémurien du Portugal. Comunicações da Direcção de Trabalhos Geológicos de Portugal 3, 210-238.

PompeckJ, J.F. 1906. Notes sur les Oxynoticeras du Sinémurien supérieur du Portugal et remarque sur le genre Oxynoticeras. Comunicações da Direcção de Trabalhos Geológicos de Portugal 6, 214-338.

Reggiani, L., Matiolli, E., Pittet, B., Duarte, L.V., Oliveira, L.C.V. \& Comas-Rengifo, M.J. 2010. Pliensbachian (Early Jurassic) calcareous nannofossils from the Peniche section (Lusitanian Basin, Portugal): a clue for palaeoenvironmental reconstructions. Marine Micropaleontology 75, 1-16. DOI 10.1016/j.marmicro.2010.02.002

Riding, J.B., Leng, M.J., Kender, S., Hesselbo, S.P. \& FEIST-BuRKhARDT, S. 2012. Isotopic and palynological evidence for a new Early Jurassic environmental perturbation. Palaeogeography, Palaeoclimatology, Palaeoecology 374, 16-27. DOI 10.1016/j.palaeo.2012.10.019

Rosales, I., Quesada, S. \& Robles, S. 2006. Geochemical arguments for identifying second-order sea-level changes in hemipelagic carbonate ramp deposits. Terra Nova 18, 233-240. DOI 10.1111/j.1365-3121.2006.00684.x

Schmid-Rohl, A., Rohl, H.-J., Oschmann, W., Frimmel, A. \& Schwark, L. 2002. Palaeoenvironmental reconstruction of lower Toarcian epicontinental black shales (Posidonia Shale, SW Germany): global versus regional control. Geobios 35, 13-20. DOI 10.1016/S0016-6995(02)00005-0

SILVA, R.L. 2013. Séries carbonatadas ricas em matéria orgânica do Jurássico da Bacia Lusitânica (Portugal): Sedimentologia, Geoquímica e interpretação paleoambiental. 250 pp. Ph.D. thesis (unpublished), University of Coimbra.

Silva, R.L., Duarte, L.V., Comas-Rengifo, M.J., Mendonça FILHO, J.G. \& AzERÊDO, A.C. 2011. Update of the carbon and oxygen isotopic records of the Early-Late Pliensbachian (Early Jurassic, 187 Ma): Insights from the organic-rich hemipelagic series of the Lusitanian Basin (Portugal). Chemical Geology 283, 177-184.

DOI 10.1016/j.chemgeo.2011.01.010

Silva, R.L, Duarte, L.V. \& MendonçA Filho, J.G. 2013. Optical 
and geochemical characterization of Upper Sinemurian (LowerJurassic) fossil wood from the Lusitanian Basin (Portugal). Geochemical Journal 47(5), 489-498.

DOI 10.2343/geochemj.2.0270

Silva, R.L., Mendonça Filho, J.G., Da Silva, F.S., Duarte, L.V., Silva, T.F., Ferreira, R. \& Azerêdo, A.C. 2012. Can biogeochemistry aid in the palaeoenvironmental/early diagenesis reconstruction of the $\sim 187$ Ma (Pliensbachian) organic-rich hemipelagic series of the Lusitanian Basin (Portugal)? Bulletin of Geosciences 87(2), 373-382.

DOI 10.3140/bull.geosci.1315

Soares, A.F., Rocha, R.B., Elmi, S., Henriques, M.H., Mouterde, R., Almeras, Y., Ruget, C., Marques, J., Duarte, L.V., Carapito, C. \& Kullberg, J.C. 1993. Le sous-bassin nord-lusitanien (Portugal) du Trias au Jurassique moyen: histoire d'un "rift avorté". Comptes rendus de l'Académie des sciences de Paris 317, 1659-1666.

Suan, G., Mattioli, E., Pittet, B., Lecuyer, C., SucherasMarx, B., Duarte, L.V., Philippe, M., Reggiani, L. \& Martineau, F. 2010. Secular environmental precursors to Early Toarcian (Jurassic) extreme climate changes. Earth and Planetary Science Letters 290, 448-458. DOI 10.1016/j.epsl.2009.12.047

Suan, G., Mattioli, E., Pittet, B., Mailliot, S. \& Lécuyer, C. 2008a. Evidence for major environmental perturbation prior to and during the Toarcian (Early Jurassic) oceanic anoxic event from the Lusitanian Basin. Paleoceanography 23, PA1202. DOI 10.1029/2007PA001459
Suan, G., Pittet, B., Bour, I., Mattioli, E., Duarte, L.V. \& Mailliot, S. 2008b. Duration of the Early Toarcian carbon isotope excursion deduced from spectral analysis: Consequences for its possible causes. Earth and Planetary Science Letters 267, 666-679. DOI 10.1016/j.eps1.2007.12.017

van De Schootbrugge, B., Bailey, T.R., Rosenthal, Y., Katz, M.E., Wright, J.D., Miller, K.G., Feist-Burkhardt, S. \& FALKOWSKI, P.G. 2005. Early Jurassic climate change and the radiation of organic-walled phytoplankton in the Tethys Ocean. Paleobiology 31, 73-97.

DOI 10.1666/0094-8373(2005)031<0073:EJCCAT>2.0.CO;2

von Breymann, M.T., Swart, P.K., Brass, G.W. \& Berner, U. 1991. Pore-water chemistry of the Sulu and Celebes Seas: extensive diagenetic reactions at Sites 767 and 768, 203-216. In Silver, E.A., Rangin, C., von Breymann, M.T. et al. Proceedings of the Ocean Drilling Program, Scientific Results 124. College Station, TX. DOI 10.2973/odp.proc.sr.124.154.1991

Wignall, P.B., Newton, R.J. \& Little, C.T.S. 2005. The timing of paleoenvironmental change and cause-and-effect relationships during the Early Jurassic mass extinction in Europe. American Journal of Science 305, 1014-1032.

DOI 10.2475/ajs.305.10.1014

Wilson, R.C.L., Hiscott, R.N., Willis, M.G. \& Gradstein, F.M. 1989. The Lusitanian Basin of west-central Portugal: Mesozoic and Tertiary tectonic, stratigraphic and subsidence history, 341-361. In TANKARD, A.J. \& BALKwILL, H.R. (eds) Extensional Tectonics and Stratigraphy of the North Atlantic Margin, AAPG Memoir 46.

\section{Appendix}

Lithostratigraphic references: ${ }^{1}$ - top of Coimbra Formation; ${ }^{2}$ - base of Polvoeira Member; ${ }^{3}$ - top of Polvoeira Member; ${ }^{4}$ - base of Praia da Pedra Lisa Member.

\begin{tabular}{|c|c|c|}
\hline $\begin{array}{c}\text { Cumulative } \\
\text { thickness }(\mathrm{cm})\end{array}$ & $\delta^{13} \mathrm{C}_{(\mathrm{PDB})} \% 0$ & $\delta^{18} \mathrm{O}_{(\mathrm{PDB})} \% 0$ \\
\hline 2.00 & 2.25 & -3.53 \\
\hline 81.50 & 2.18 & -4.15 \\
\hline 143.00 & 2.03 & -2.81 \\
\hline 352.00 & 1.90 & $-3.97^{1}$ \\
\hline 465.50 & 1.51 & $-3.09^{2}$ \\
\hline 533.00 & 1.90 & -3.87 \\
\hline 679.50 & 2.23 & -2.87 \\
\hline 693.00 & 2.82 & -3.27 \\
\hline 744.50 & 1.72 & -3.54 \\
\hline 788.00 & 2.85 & -3.48 \\
\hline 853.00 & 2.27 & -3.52 \\
\hline 896.00 & 1.11 & -3.71 \\
\hline 904.00 & 2.02 & -3.74 \\
\hline 998.00 & 1.48 & -4 \\
\hline 1013.50 & 2.19 & -4.09 \\
\hline 1109.00 & 1.37 & -4.03 \\
\hline 1129.00 & 1.24 & -4.46 \\
\hline 1188.00 & 1.32 & -4.27 \\
\hline 1230.00 & 1.16 & -3.64 \\
\hline
\end{tabular}

\begin{tabular}{|c|c|c|}
\hline $\begin{array}{c}\text { Cumulative } \\
\text { thickness }(\mathrm{cm})\end{array}$ & $\delta^{13} \mathrm{C}_{(\mathrm{PDB})} \%$ \% & $\delta^{18} \mathrm{O}_{(\mathrm{PDB})} \% 0$ \\
\hline 1260.00 & 1.36 & -3.74 \\
\hline 1379.00 & 0.63 & -2.89 \\
\hline 1379.00 & 0.69 & -2.89 \\
\hline 1386.00 & -0.21 & -4.91 \\
\hline 1411.00 & -0.16 & -4.67 \\
\hline 1441.00 & 0.46 & -3.69 \\
\hline 1437.00 & 0.47 & -4.79 \\
\hline 1446.50 & 1.05 & -4.31 \\
\hline 1469.50 & 0.92 & -4.61 \\
\hline 1599.00 & 0.98 & -3.34 \\
\hline 1617.00 & 0.38 & -3.37 \\
\hline 1630.00 & 1.47 & -3.49 \\
\hline 1714.00 & 1.49 & -3.61 \\
\hline 1806.00 & 0.68 & -4.30 \\
\hline 1820.00 & 1.52 & -4.29 \\
\hline 2092.00 & 1.42 & -4.28 \\
\hline 2193.00 & 1.36 & -4.22 \\
\hline 2215.50 & 0.58 & -4.01 \\
\hline 2227.00 & 1.34 & -4.46 \\
\hline
\end{tabular}

\begin{tabular}{|c|c|c|}
\hline $\begin{array}{c}\text { Cumulative } \\
\text { thickness }(\mathrm{cm})\end{array}$ & $\delta^{13} \mathrm{C}_{(\mathrm{PDB})} \%$ \% & $\delta^{18} \mathrm{O}_{(\mathrm{PDB})} \%$ \\
\hline 2236.00 & 1.12 & -4.43 \\
\hline 2240.00 & 1.72 & -4.75 \\
\hline 2246.00 & 1.24 & -4.32 \\
\hline 2246.00 & 1.20 & -4.36 \\
\hline 2258.00 & 1.07 & -3.79 \\
\hline 2268.00 & 1.58 & -4.87 \\
\hline 2271.00 & 1.40 & -5.01 \\
\hline 2277.00 & 1.62 & -4.88 \\
\hline 2297.00 & 1.34 & -4.15 \\
\hline 2311.00 & 0.01 & -3.38 \\
\hline 2316.00 & -1.21 & -3.14 \\
\hline 2323.00 & 1.10 & -4.52 \\
\hline 2327.00 & 1.57 & -5.16 \\
\hline 2329.00 & 1.54 & -4.96 \\
\hline 2335.00 & 0.98 & -3.85 \\
\hline 2350.00 & 0.43 & -3.42 \\
\hline 2368.00 & 0.90 & -4.18 \\
\hline 2376.00 & 1.57 & -4.80 \\
\hline 2376.00 & 1.59 & -4.75 \\
\hline
\end{tabular}




\begin{tabular}{|c|c|c|}
\hline $\begin{array}{c}\text { Cumulative } \\
\text { thickness }(\mathrm{cm})\end{array}$ & $\delta^{13} \mathrm{C}_{(\mathrm{PDB})} \%$ & $\delta^{18} \mathrm{O}_{(\mathrm{PDB})} \% o$ \\
\hline 2386.00 & 1.51 & -4.27 \\
\hline 2399.00 & 1.24 & -3.76 \\
\hline 2414.00 & 1.52 & -4.20 \\
\hline 2429.00 & 1.29 & -3.92 \\
\hline 2439.00 & 1.13 & -3.74 \\
\hline 2459.00 & 1.07 & -4.21 \\
\hline 2474.00 & -0.07 & -4.03 \\
\hline 2474.00 & -0.13 & -3.97 \\
\hline 2479.00 & 1.75 & -4.76 \\
\hline 2515.00 & 0.89 & -4.57 \\
\hline 2540.00 & 1.06 & -3.95 \\
\hline 2542.00 & 1.12 & -4.40 \\
\hline 2547.00 & 1.61 & -4.78 \\
\hline 2554.50 & 1.28 & -4.77 \\
\hline 2592.50 & 1.42 & -4.54 \\
\hline 2597.00 & 1.33 & -4.02 \\
\hline 2617.00 & 0.82 & -3.32 \\
\hline 2636.00 & 1.53 & -4.36 \\
\hline 2638.00 & 1.48 & -4.06 \\
\hline 2644.00 & 1.54 & -3.79 \\
\hline 2655.00 & 0.97 & -3.71 \\
\hline 2670.00 & 1.09 & -3.72 \\
\hline 2684.00 & 0.75 & -4.26 \\
\hline 2694.00 & 0.91 & -4.28 \\
\hline 2713.00 & 1.29 & -4.46 \\
\hline 2723.00 & 0.84 & -4.51 \\
\hline 2733.00 & 1.31 & -4.46 \\
\hline 2743.00 & 1.62 & -4.54 \\
\hline 2778.00 & 1.47 & -4.62 \\
\hline 2780.00 & 1.25 & -4.44 \\
\hline 2784.00 & 1.39 & -4.40 \\
\hline 2784.00 & 1.40 & -4.45 \\
\hline 2786.00 & 1.60 & -4.37 \\
\hline 2788.00 & 1.47 & -4.38 \\
\hline 2789.00 & 0.84 & -4.41 \\
\hline 2789.00 & 0.91 & -4.23 \\
\hline 2790.00 & 0.72 & -4.05 \\
\hline 2795.00 & 0.11 & -3.74 \\
\hline 2803.00 & 1.45 & -4.39 \\
\hline 2822.00 & 0.81 & -3.59 \\
\hline 2825.00 & 0.46 & -3.05 \\
\hline 2839.50 & 1.26 & -4.23 \\
\hline 2853.00 & 0.92 & -3.41 \\
\hline 2872.00 & 0.87 & -3.72 \\
\hline 2888.00 & 0.84 & -3.87 \\
\hline 2901.00 & 0.89 & -3.51 \\
\hline 2905.00 & 1.09 & -3.83 \\
\hline 2921.00 & 0.43 & -4.05 \\
\hline 2930.00 & 1.06 & -4.51 \\
\hline 2931.00 & 0.90 & -4.40 \\
\hline
\end{tabular}

\begin{tabular}{|c|c|c|}
\hline $\begin{array}{c}\text { Cumulative } \\
\text { thickness }(\mathrm{cm})\end{array}$ & $\delta^{13} \mathrm{C}_{(\mathrm{PDB})} \%$ & $\delta^{18} \mathrm{O}_{(\mathrm{PDB})} \%$ \\
\hline 2937.00 & 0.64 & -4.54 \\
\hline 2947.00 & 0.45 & -4.34 \\
\hline 2971.00 & 0.91 & -4.05 \\
\hline 2971.00 & 0.89 & -4.02 \\
\hline 2981.00 & 1.02 & -4.37 \\
\hline 2991.00 & 0.93 & -4.44 \\
\hline 3001.00 & 0.86 & -3.73 \\
\hline 3007.00 & 1.03 & -4.25 \\
\hline 3025.00 & -5.62 & -2.12 \\
\hline 3042.00 & 0.89 & -4.60 \\
\hline 3045.00 & 0.77 & -4.63 \\
\hline 3048.00 & 0.57 & -4.51 \\
\hline 3048.00 & 0.56 & -4.53 \\
\hline 3053.00 & 0.52 & -4.47 \\
\hline 3063.00 & 1.12 & -4.38 \\
\hline 3070.00 & 1.00 & -4.69 \\
\hline 3076.00 & 0.89 & -4.08 \\
\hline 3084.00 & 0.84 & -4.02 \\
\hline 3084.00 & 0.83 & -3.98 \\
\hline 3091.00 & 0.95 & -4.24 \\
\hline 3113.00 & 0.71 & -3.80 \\
\hline 3120.00 & 0.82 & -4.36 \\
\hline 3126.00 & 0.82 & -4.31 \\
\hline 3138.00 & 1.02 & -4.37 \\
\hline 3172.00 & 1.05 & -4.51 \\
\hline 3176.00 & 0.88 & -4.32 \\
\hline 3176.00 & 0.87 & -4.42 \\
\hline 3178.50 & 0.96 & -4.73 \\
\hline 3181.00 & 0.84 & -4.45 \\
\hline 3183.50 & 0.88 & -4.66 \\
\hline 3184.00 & 0.55 & -4.45 \\
\hline 3187.00 & 1.00 & -5.15 \\
\hline 3187.00 & 1.13 & -5.19 \\
\hline 3189.00 & 0.86 & -4.47 \\
\hline 3191.00 & 0.71 & -4.05 \\
\hline 3195.50 & -0.02 & -3.51 \\
\hline 3201.00 & 0.58 & -4.32 \\
\hline 3210.00 & -4.49 & -2.22 \\
\hline 3217.00 & -1.57 & -3.87 \\
\hline 3224.00 & -4.58 & -2.08 \\
\hline 3239.00 & 0.17 & -3.82 \\
\hline 3247.00 & 0.55 & -4.95 \\
\hline 3252.00 & 0.27 & -4.82 \\
\hline 3261.00 & 0.52 & -5.61 \\
\hline 3267.00 & 0.54 & -4.63 \\
\hline 3272.00 & 0.10 & -3.93 \\
\hline 3280.00 & 0.10 & -4.76 \\
\hline 3285.00 & 0.59 & -5.28 \\
\hline 3300.00 & 0.07 & -4.28 \\
\hline 3310.00 & 0.31 & -5.07 \\
\hline
\end{tabular}

\begin{tabular}{|c|c|c|}
\hline $\begin{array}{c}\text { Cumulative } \\
\text { thickness }(\mathrm{cm})\end{array}$ & $\delta^{13} \mathrm{C}_{(\mathrm{PDB})} \% 0$ & $\delta^{18} \mathrm{O}_{(\mathrm{PDB})} \% 0$ \\
\hline 3326.00 & 0.11 & -4.57 \\
\hline 3335.50 & 0.23 & -4.90 \\
\hline 3346.00 & 0.44 & -4.21 \\
\hline 3349.00 & 0.91 & -4.96 \\
\hline 3351.50 & 0.80 & -4.48 \\
\hline 3354.00 & 1.08 & -4.50 \\
\hline 3356.00 & 0.84 & -4.42 \\
\hline 3359.00 & 0.97 & -4.47 \\
\hline 3359.00 & 0.98 & -4.46 \\
\hline 3364.00 & 1.01 & -4.29 \\
\hline 3371.00 & 1.03 & -4.57 \\
\hline 3373.00 & 1.02 & -4.58 \\
\hline 3376.50 & 0.79 & -4.78 \\
\hline 3381.00 & 0.15 & -3.69 \\
\hline 3386.00 & -5.76 & -2.69 \\
\hline 3394.00 & 0.34 & -4.76 \\
\hline 3394.00 & -6.71 & -2.45 \\
\hline 3402.00 & -5.28 & -2.75 \\
\hline 3408.00 & 0.82 & -5.01 \\
\hline 3419.00 & 0.30 & -4.33 \\
\hline 3434.00 & 0.94 & -5.08 \\
\hline 3444.00 & 0.23 & -4.75 \\
\hline 3449.00 & 0.32 & -4.50 \\
\hline 3452.00 & 0.33 & -4.69 \\
\hline 3452.00 & 0.36 & -4.63 \\
\hline 3459.00 & 0.73 & -4.96 \\
\hline 3459.00 & 0.69 & -4.94 \\
\hline 3463.00 & 0.48 & -4.52 \\
\hline 3467.00 & 0.79 & -4.95 \\
\hline 3476.00 & 0.51 & -4.76 \\
\hline 3486.00 & 0.34 & -3.91 \\
\hline 3486.50 & 0.06 & -5.42 \\
\hline 3491.00 & 0.34 & -4.99 \\
\hline 3499.00 & 0.67 & -4.92 \\
\hline 3499.00 & 0.63 & -5.00 \\
\hline 3511.00 & -2.64 & -3.71 \\
\hline 3521.00 & 0.31 & -4.18 \\
\hline 3531.00 & -0.61 & -4.21 \\
\hline 3538.00 & 0.09 & -4.76 \\
\hline 3555.00 & -0.01 & -4.60 \\
\hline 3565.00 & 0.41 & -4.38 \\
\hline 3576.00 & 0.29 & -4.70 \\
\hline 3578.00 & 0.22 & -4.95 \\
\hline 3578.00 & 0.27 & -5.03 \\
\hline 3595.00 & 0.13 & -4.24 \\
\hline 3598.00 & 0.11 & -4.37 \\
\hline 3603.00 & 0.38 & -5.24 \\
\hline 3607.00 & 0.16 & -4.15 \\
\hline 3612.00 & 0.60 & -4.74 \\
\hline 3615.00 & 0.50 & -4.64 \\
\hline
\end{tabular}




\begin{tabular}{|c|c|c|}
\hline $\begin{array}{c}\text { Cumulative } \\
\text { thickness }(\mathrm{cm})\end{array}$ & $\delta^{13} \mathrm{C}_{(\mathrm{PDB})} \% o$ & $\delta^{18} \mathrm{O}_{(\mathrm{PDB})} \% o$ \\
\hline 3620.00 & 0.76 & -4.81 \\
\hline 3628.00 & 0.50 & -4.64 \\
\hline 3632.00 & 0.47 & -4.66 \\
\hline 3643.00 & 0.26 & -5.18 \\
\hline 3653.00 & 0.06 & -4.59 \\
\hline 3656.00 & 0.80 & -4.93 \\
\hline 3659.00 & 0.56 & -4.60 \\
\hline 3666.00 & -0.04 & -4.19 \\
\hline 3681.00 & 0.22 & -4.77 \\
\hline 3693.00 & -0.52 & -4.48 \\
\hline 3699.00 & -0.94 & -4.00 \\
\hline 3707.00 & 0.22 & -5.05 \\
\hline 3708.00 & 0.06 & -5.09 \\
\hline 3722.00 & -0.14 & -4.60 \\
\hline 3737.00 & 0.46 & -5.43 \\
\hline 3745.00 & 0.17 & -4.69 \\
\hline 3760.00 & 0.22 & -4.69 \\
\hline 3772.00 & 0.62 & -5.09 \\
\hline 3780.00 & 0.27 & -4.53 \\
\hline 3794.50 & 0.34 & -4.20 \\
\hline 3807.00 & 0.05 & -5.25 \\
\hline 3815.00 & 0.37 & -4.91 \\
\hline 3838.50 & 0.16 & -4.35 \\
\hline 3850.00 & 0.57 & -5.13 \\
\hline 3869.00 & -0.47 & -4.28 \\
\hline 3879.00 & -0.25 & -5.10 \\
\hline 3894.00 & 0.82 & -5.02 \\
\hline 3899.00 & 0.57 & -4.94 \\
\hline 3909.00 & 0.44 & -4.94 \\
\hline 3923.50 & 0.57 & -4.53 \\
\hline 3933.00 & 0.30 & -5.01 \\
\hline 3943.50 & 0.05 & -4.53 \\
\hline 3954.00 & -0.03 & -4.82 \\
\hline 3961.00 & -1.03 & -5.02 \\
\hline 3974.00 & -0.92 & -5.03 \\
\hline 3989.00 & 0.03 & -5.14 \\
\hline 3999.00 & 0.02 & -5.21 \\
\hline 4009.00 & 0.18 & -5.25 \\
\hline 4014.00 & 0.06 & -5.25 \\
\hline 4017.00 & 0.05 & -4.92 \\
\hline 4021.00 & 0.16 & -4.75 \\
\hline 4023.00 & -0.62 & -4.21 \\
\hline 4029.00 & 0.32 & -4.97 \\
\hline 4033.00 & 0.55 & -5.04 \\
\hline 4036.00 & 0.26 & -4.80 \\
\hline 4044.00 & -0.38 & -5.40 \\
\hline 4054.00 & -0.37 & -5.27 \\
\hline 4064.00 & -0.88 & -5.29 \\
\hline
\end{tabular}

\begin{tabular}{|c|c|c|}
\hline $\begin{array}{c}\text { Cumulative } \\
\text { thickness }(\mathrm{cm})\end{array}$ & $\delta^{13} \mathrm{C}_{(\mathrm{PDB})} \%$ & $\delta^{18} \mathrm{O}_{(\mathrm{PDB})} \%$ \\
\hline 4082.00 & -0.35 & -5.15 \\
\hline 4087.00 & -0.13 & -5.06 \\
\hline 4104.00 & -0.36 & -3.52 \\
\hline 4114.00 & 0.13 & -4.93 \\
\hline 4129.00 & 0.17 & -5.12 \\
\hline 4144.00 & 0.16 & -4.95 \\
\hline 4168.00 & -0.39 & -4.92 \\
\hline 4181.00 & 0.52 & -5.09 \\
\hline 4185.00 & -0.88 & -4.48 \\
\hline 4185.00 & -0.93 & -4.40 \\
\hline 4199.00 & -0.38 & -3.76 \\
\hline 4222.00 & -2.64 & -2.35 \\
\hline 4240.00 & 0.00 & -5.02 \\
\hline 4245.00 & 0.37 & -5.01 \\
\hline 4291.00 & 0.22 & -5.27 \\
\hline 4303.00 & -0.10 & -5.13 \\
\hline 4313.00 & 0.29 & -4.83 \\
\hline 4322.00 & -3.02 & -1.39 \\
\hline 4331.00 & 0.46 & -4.87 \\
\hline 4339.00 & 0.72 & -5.21 \\
\hline 4348.00 & 0.29 & -4.91 \\
\hline 4358.50 & 0.90 & -4.68 \\
\hline 4369.50 & -0.79 & -2.72 \\
\hline 4380.00 & 0.55 & -4.64 \\
\hline 4396.00 & -0.96 & -4.69 \\
\hline 4409.00 & -1.44 & -2.02 \\
\hline 4421.00 & 0.56 & -4.88 \\
\hline 4428.00 & -0.11 & -5.04 \\
\hline 4435.00 & 0.27 & -4.63 \\
\hline 4445.50 & -1.30 & -2.16 \\
\hline 4461.00 & -0.14 & -4.71 \\
\hline 4471.00 & -0.12 & -4.45 \\
\hline 4471.00 & -0.18 & -4.54 \\
\hline 4481.00 & 0.45 & -4.64 \\
\hline 4505.00 & 0.34 & -4.85 \\
\hline 4505.00 & 0.37 & -4.79 \\
\hline 4525.50 & -0.03 & -4.97 \\
\hline 4538.50 & -0.04 & -4.65 \\
\hline 4550.00 & 0.56 & -4.34 \\
\hline 4560.00 & -2.00 & -1.99 \\
\hline 4565.00 & -0.19 & -3.21 \\
\hline 4581.00 & 0.45 & -4.65 \\
\hline 4586.00 & 0.62 & -4.58 \\
\hline 4596.00 & -0.01 & -5.20 \\
\hline 4604.00 & -0.15 & -2.79 \\
\hline 4608.00 & -0.06 & -3.20 \\
\hline 4618.00 & 0.15 & -5.22 \\
\hline 4622.00 & 1.08 & -4.44 \\
\hline
\end{tabular}

\begin{tabular}{|c|c|c|}
\hline $\begin{array}{c}\text { Cumulative } \\
\text { thickness }(\mathrm{cm})\end{array}$ & $\delta^{13} \mathrm{C}_{(\mathrm{PDB})} \% o$ & $\delta^{18} \mathrm{O}_{(\mathrm{PDB})} \% o$ \\
\hline 4625.00 & 0.69 & -4.67 \\
\hline 4634.00 & -0.55 & -4.99 \\
\hline 4639.00 & -0.82 & -5.01 \\
\hline 4639.00 & -0.87 & -5.13 \\
\hline 4653.00 & 0.25 & -4.84 \\
\hline 4670.00 & -0.25 & -5.24 \\
\hline 4680.00 & 0.23 & $-4.91^{3}$ \\
\hline 4700.00 & 0.60 & $-3.62^{4}$ \\
\hline 4735.00 & 0.68 & -4.22 \\
\hline 4752.00 & 0.71 & -5.07 \\
\hline 4822.00 & 0.72 & -3.84 \\
\hline 4924.00 & 0.99 & -4.17 \\
\hline 5000.00 & 1.04 & -4.77 \\
\hline 5035.00 & 1.13 & -4.29 \\
\hline 5180.00 & 1.34 & -3.16 \\
\hline 5234.00 & 1.00 & -3.21 \\
\hline 5282.00 & 1.24 & -3.77 \\
\hline 5282.00 & 0.98 & -3.99 \\
\hline 5291.00 & 1.02 & -3.79 \\
\hline 5298.00 & 1.26 & -2.99 \\
\hline 5302.00 & 1.14 & -3.42 \\
\hline 5312.00 & 1.08 & -3.52 \\
\hline 5316.00 & 1.06 & -4.01 \\
\hline 5324.00 & 1.12 & -3.53 \\
\hline 5324.00 & 0.95 & -3.61 \\
\hline 5332.00 & 1.01 & -3.92 \\
\hline 5340.00 & 0.91 & -3.49 \\
\hline 5344.00 & 0.97 & -4.15 \\
\hline 5348.00 & 0.99 & -4.39 \\
\hline 5363.00 & 0.99 & -4.08 \\
\hline 5544.00 & 1.33 & -3.43 \\
\hline 5562.00 & 1.39 & -3.70 \\
\hline 5589.00 & 0.95 & -3.55 \\
\hline 5640.00 & 1.05 & -4.02 \\
\hline 5660.00 & -0.23 & -4.31 \\
\hline 5700.00 & 0.98 & -4.30 \\
\hline 5713.00 & 0.82 & -3.85 \\
\hline 5762.00 & 1.16 & -3.91 \\
\hline 5762.00 & 1.02 & -3.71 \\
\hline 5817.00 & 0.86 & -3.75 \\
\hline 5869.00 & 0.58 & -3.44 \\
\hline 5915.00 & 0.87 & -3.76 \\
\hline 5982.00 & 0.40 & -4.27 \\
\hline 6039.00 & -0.69 & -3.15 \\
\hline 6097.00 & 0.62 & -4.57 \\
\hline 6113.00 & 0.91 & -4.60 \\
\hline 6118.00 & 0.34 & -3.50 \\
\hline 6232.00 & 0.77 & -3.22 \\
\hline
\end{tabular}

